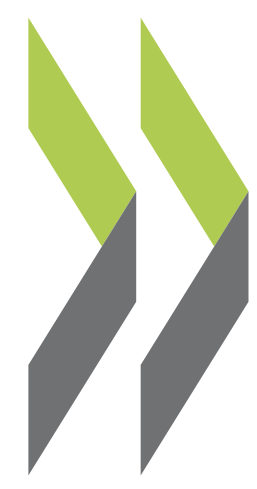

OECD Working Papers on Insurance and Private Pensions No. 8

Pension Fund Regulation and Risk Management: Results from an ALM Optimisation Exercise
Sandra Blome,

Kai Fachinger,

Dorothee Franzen, Gerhard Scheuenstuhl,

\section{Juan Yermo}




\section{खеC}

PENSION FUND REGULATION AND RISK MANAGEMENT: RESULTS FROM AN ALM OPTIMISATION EXERCISE

S. Blome, K. Fachinger, D. Franzen, G. Scheuenstuhl, and J. Yermo

May 2007

OECD WORKING PAPER ON INSURANCE AND PRIVATE PENSIONS

No. 8

Financial Affairs Division, Directorate for Financial and Enterprise Affairs

Organisation for Economic Co-operation and Development

2 Rue André Pascal, Paris 75116, France

www.oecd.org/daf/fin/wp 


\section{ABSTRACT \\ Pension Fund Regulation and Risk Management: Results from an ALM Optimisation Exercise}

This paper provides a stylised assessment of the impact of investment-relevant pension fund regulations and accounting rules on contribution and investment strategies within the context of an asset-liability model (ALM) specifically designed for this purpose. The analysis identifies a substantial impact of regulations which, in a simplified way, resemble those in place in Germany, Japan, the Netherlands, United Kingdom and the United States. The ALM model shows that regulations affect funding costs primarily through the choice of investment strategy. Strict funding regulations may force sponsors to make up funding shortfalls in bad economic times and lead them to invest more conservatively, which ultimately raises net funding costs. The paper also shows that fairvalue accounting standards (with immediate recognition of actuarial gains and losses) can contribute to higher funding levels than required by regulators.

JEL codes: G23, J32

Keywords: Pension funds, defined benefit, asset liability management, investment, discount rates, accounting, valuation methods, actuarial methods, fair value.

$$
* * * * *
$$

\section{RÉSUMÉ}

\section{Réglementation des organismes de retraite et gestion des risques : résultats d'un exercice d'optimisation fondé sur un modèle de GAP}

Nous présentons dans cette étude une évaluation simplifiée de l'impact qu'ont les règles comptables et les dispositions réglementaires applicables aux organismes de retraite en matière de placements sur les stratégies de cotisation et d'investissement, dans le cadre d'un modèle de gestion actif-passif (GAP) spécialement élaboré à cet effet. Nous mettons en évidence l'existence d'un impact sensible des dispositions réglementaires qui, pour simplifier, ressemblent à celles qui sont en vigueur en Allemagne, aux États-Unis, au Japon, aux Pays-Bas et au Royaume-Uni. Le modèle de GAP montre que l'influence exercée par les dispositions réglementaires sur le coût des capitaux passe essentiellement par le choix de la stratégie d'investissement. Une réglementation stricte en matière de financement peut contraindre les promoteurs de plans de retraite à combler les déficits de financement en période de conjoncture économique défavorable, et les amener à investir avec davantage de prudence, ce qui entraîne à terme une augmentation du coût net des capitaux. Nous montrons également dans cette étude que les normes de comptabilisation à la juste valeur (impliquant la prise en compte immédiate des gains et pertes actuariels) peuvent contribuer à des niveaux de financement plus élevés que ceux requis par les autorités de réglementation.

Classification JEL : G23, J32

Mots-clés : organismes de retraite, prestation définie, gestion actif-passif, investissement, taux d'actualisation, comptabilité, méthodes d'évaluation, méthodes actuarielles, juste valeur.

\section{Copyright OECD, 2007}

Applications for permission to reproduce or translate all, or part of, this material should be made to: Head of Publications Service, OECD, 2 rue André-Pascal, 75775 Paris Cédex 16, France. 


\title{
PENSION FUND REGULATION AND RISK MANAGEMENT: RESULTS FROM AN ALM OPTIMISATION EXERCISE
}

\author{
S. Blome, K. Fachinger, D. Franzen, G. Scheuenstuhl, and J. Yermo ${ }^{*}$
}

\section{Introduction}

This paper provides a stylised assessment of the impact of investmentrelevant pension fund regulations and accounting rules on contribution and investment strategies within the context of an asset-liability model (ALM) specifically designed for this purpose. ${ }^{1}$ The regulations and accounting rules considered represent, in a simplified way, the situation in Germany, Japan, the Netherlands, United Kingdom and United States. ${ }^{2}$ These countries were studied for their differences in regulations, including some major regulatory initiatives in recent years, as well for the size of their defined benefit (DB) systems. The analysis could in principle be extended to other countries or regulations.

The pension fund industry in these countries has undergone a major upheaval over the last few years. Japanese pension funds were first to be affected, as weak economic conditions have prevailed for most of the period since the prickling in 1990 of the property and stock market bubble.

Sandra Blome and Kai Fachinger are at IFA (Germany), Dorothee Franzen is at Oxford University (United Kingdom), Gerhard Scheuenstuhl is at risklab germany (Germany), and Juan Yermo is at the OECD. This article is the result of a joint research project between Allianz GI, risklab germany and the OECD, and received useful inputs from Brigitte Miksa (Allianz GI), a group of external advisers, including Con Keating (Finance Development Centre, United Kingdom), Niels Kortleve (PGGM, Netherlands) and Peter Vlaar (DNB, Netherlands), as well as the Delegates to the OECD Working Party on Private Pensions and the OECD Secretariat (Pablo Antolín, André Laboul and Fiona Stewart). The views expressed are the sole responsibility of the authors and do not necessarily reflect those of the OECD or its member countries.

Contact information: Juan Yermo, Financial Affairs Division, Directorate for Financial and Enterprise Affairs, Organization for Economic Co-operation and Development, 2, rue André Pascal, Paris 75116, France. E-mail: juan.yermo@oecd.org 
OECD Working Paper on Insurance and Private Pensions

Occupational DB plans in the United Kingdom and the United States were dealt a severe blow by the 2000-1 stock market crash and the ensuing low interest rate environment, creating large funding gaps after almost a decade of contribution holidays. On the other hand, pension funds in Germany and the Netherlands, while also adversely affected by these market corrections, have generally maintained funding levels (the ratio of pension plan assets to liabilities) above the solvency level established by the regulation.

Short term regulatory action has taken diverse forms, some corrective (leading ultimately to increases in contributions), some lenient (allowing temporary reduction in statutory contributions). Going forward, however, there is a general consensus among OECD countries for reforming regulatory and supervisory systems so that they better meet the objective of benefit security without jeopardising plan continuity. New pension fund regulations have been approved in the Netherlands, the United Kingdom and the United States with precisely these goals in mind. The general trend is towards greater surveillance of funding levels, to avoid situations where pension plans need to be closed (normally, because of bankruptcy of the plan sponsor) but plan assets are insufficient to meet benefit promises.

Looking closer, however, two rather different models of regulation can be identified, epitomised by the new UK and Dutch regulatory systems. The UK system is characterised by a flexible approach to funding (there is no statutory minimum funding requirement) and a strict, risk-based sponsor insolvency insurance fund, the Pension Protection Fund. The Dutch system, on the other hand, offers no explicit insolvency insurance but has relatively strict funding rules, including a requirement to fund at least $105 \%$ of the pension fund liability in nominal terms (excluding both salary projection for revaluing accrued benefits and indexation of benefits in payment) and a regular assessment of the buffers built to finance the fund's revaluation and indexation ambitions.

Another important aspect of the external environment that affects pension fund investment decisions is the accounting of pension expenses by DB plan sponsors, which have changed substantially over the last two decades. Starting with the US standard SFAS87 in 1985, actuarial valuation methods have been gradually replaced throughout the OECD by a marketbased valuation approach. The traditional actuarial approach focused on the long-term stability of estimated contributions necessary to fund pension payment. Pension funds' assets and liabilities were valuated at fixed, smoothed or long-term expected rates. The market-based approach, on the other hand, applies market prices to pension funds' assets and liabilities thereby enhancing the transparency and comparability of the financial position of the fund. ${ }^{3}$ According to advocates of the new approach only the consistent and consequent application of fair value principles enables 
OECD Working Paper on Insurance and Private Pensions

pension funds to conduct an objective risk assessment. On the other hand, this approach has been criticised for introducing inappropriate volatility to the liabilities and for leading to short-termist investment strategies. Some observers $^{4}$ also argue that market-based valuations, and in particular the UK's FRS17 standard, may have contributed to the decline of DB plans. ${ }^{5}$

Also, the new accounting standards require pension liabilities to be calculated applying the projected unit credit method, thereby leading to a different measure of liabilities compared to regulatory standards, which typically require the recognition and funding of the accrued benefits only (without projecting salaries at retirement). ${ }^{6}$

Assessing the pros and cons of different regulations and accounting standards requires an evaluation of their impact on funding levels (hence, benefit security), investment performance (hence, benefit levels) and funding cost (hence, plan continuity). While a full assessment of these regulations and accounting is beyond the scope of this exercise, the present paper attempts to elucidate some basic facts through an ALM exercise. Such models are increasingly being used by pension funds to assess their investment strategies.

The paper is organised as follows. Section 2 provides an introduction to the literature on risk management models and their application to pension funds. Section 3 presents the risk management model and the main results of the assessment of five different regulatory systems which are simplifications of the existing framework in five OECD countries (Germany, Japan, the Netherlands, United Kingdom and the United States). The last Section concludes. The appendix describes the typical DB plan design and regulations in each of the five countries covered in the study.

\section{Developments in pension fund risk management}

Risk management is becoming an increasingly sophisticated and central function within financial institutions. In DB pension funds, risk management involves the measurement and assessment of pension fund risks and the design, monitoring and revision of the fund's parameters (contributions, benefits, and investments) in order to address these risks in line with the funds' objectives.

The main risks that DB pension funds are exposed to are investment, inflation, and longevity risk..$^{7}$ In turn, plan members are exposed to the risk that pension fund assets will be insufficient to cover benefit promises if the plan is terminated (typically, because of bankruptcy of the plan sponsor). In order to meet the needs of both plan sponsors and plan members, risk management should have the following two goals: 
OECD Working Paper on Insurance and Private Pensions

- Minimising the pension cost to contributors.

- Minimising the risk of benefit cuts to beneficiaries.

These goals involve trade-offs between contributions, asset allocation and risk, as the objectives of the stakeholders can (and do) vary. Plan sponsors are most interested in minimising the net funding cost of a plan by optimising the risk-adjusted return on plan assets. Plan members usually follow multiple goals that change over time: In case of member contributions, they share employers' goal of minimising pension costs. As active members, they are generally concerned with maximising their plan benefits without running the risk of losing vested benefits. Retired members usually place higher emphasis on benefit security as they have less or no time left to make up any shortfalls. As the pension promise is ultimately backed by the employer, insolvency of the plan sponsor forms the most basic risk to beneficiaries. This risk can be either dealt with by pension insurance arrangements (publicly set-up protection funds or private insurance) or via high funding buffers in the pension fund itself. Risk management's task, therefore, consists in unravelling these different objectives and constraints into a consistent combination of benefit and contribution policies and funding and investment strategies that satisfy plan sponsors and plan members, both active and retired.

Asset-liability modelling (ALM) is a key method in strategic risk management. ${ }^{8}$ ALM is a financial risk assessment and asset planning tool used by pension funds to help them choose the strategic pension policy under uncertainty in a coherent and consistent balance sheet approach. ${ }^{9}$ ALM involves developing mathematical scenarios of the future evolution of pension fund assets and liabilities, given certain assumptions about the statistical properties of economic, financial and biometric variables that affect the evolution of assets and liabilities. There are many ways to generate economic, actuarial and financial market scenarios. The traditional method was to create a central scenario and to carry out some stress testing around it.

With time the models have become more sophisticated, moving from the 'one-period static' type to 'multi-period dynamic' models involving the consistent stochastic simulation of assets and liabilities (which run multiple 'Monte Carlo' simulations). Modern ALM studies rely on stochastic models that generate thousands of scenarios with different probabilities attached to each. While the traditional ALM studies focused on asset-optimisation with a deterministic view on liabilities, today the ALM context is increasingly used to simulate the consequences of pension policies on different stakeholders while complying with the requirements of the regulating authorities. In this sense, ALM systems are used as integrated planning systems to simultaneously determine investment, funding and - if applicable - indexation policies thereby 
balancing the goals of the different stakeholders ${ }^{10}$ Risk is usually conceptualised as adverse development of the key variables, e.g. funding level, which has explicitly to be decided on. This has been taken further: by discounting the results of the ALM study back to present by applying riskadjusted discount rates, risk becomes endogenous. Under such a 'value-based ALM' contributions have a higher opportunity cost in bad economic times. As poor equity returns coincide with periods of economic weakness, a 'value-based ALM' may lead to lower optimal equity allocations. ${ }^{11}$

ALM studies are common in all the countries covered by this paper, however there are differences in how they are carried out, and the stringency with which the resulting strategic asset allocation is implemented. In all countries, ALM studies are carried out by outside actuaries or consultants; only the very large Dutch and US funds run ALM studies internally, often in parallel to an externally conducted study. Dutch pension funds can be regarded as most sophisticated in terms of ALM. In the Netherlands, ALM is a widely accepted risk management tool. The new regulatory framework introduced in January 2007 requires the use of ALM studies, with stochastic analysis prescribed as of 2010. Germany also requires 'Pensionskassen' to regularly perform an ALM study, although the German market still lacks the Dutch sophistication. In the United Kingdom, on the other hand, there are still reservations against ALM, as the ALM models do not take account of the sponsor's covenant, on which the pension promise in the UK is based. There are also some reservations against the mathematical approach dating back to the Myner's Review. ${ }^{12}$

Though dynamic models have proven a better fit for the real world scenarios encountered by pension funds they do have their drawbacks, partly due to their complexity, making it harder for fund trustees or directors to understand and interpret. Arguably, in some countries investment oversight and trustee training have not always been able to keep pace with improvements in the sophistication of mathematical modelling techniques.

Furthermore, it has been proclaimed that many ALM studies generated high-risk, high-return portfolios, rather than strictly liability- matching portfolios $^{13}$, as it is proposed by a school in financial economics that proclaims pension funds should avoid exposing sponsoring employers to risks that can be taken directly by shareholders of the sponsoring company ${ }^{14}$. The coherent implementation of risk-immunising portfolios lies at the heart of the new 'Liability-Driven-Investment' (LDI) strategies, the understanding of which, however, varies across countries. In its general meaning, which is mostly applied in the Netherlands, for example, LDI refers to an investment strategy that is aligned with the liabilities of an investor and explicitly considers their stochastic nature. The impact of relative differences between liabilities and assets on the goals and constraints set by the decision maker 
OECD Working Paper on Insurance and Private Pensions

make it crucial to look at both sides simultaneously. In the UK context, LDI concepts aim to immunize the sponsor from certain risk factors. Duration and cash flow matching strategies aim at eliminating interest rate risks. Other risk dimensions like inflation or mortality risks however cannot be properly addressed for lack of adequate financial products. In general, liabilities have become much more important for determining the optimal investment policy, and therefore the valuation methodology applied to pension funds' liabilities.

The use of risk management techniques such as ALM and LDI has been felt most strongly in investment strategies. Two main developments have been observed in the countries covered by this study:

- A move towards greater duration of fixed income portfolios and greater use of derivative instruments to hedge interest rate risk.

- Greater investment in so-called alternative instruments, such as private equity, real estate and hedge funds in search of the elusive "alpha".

Professional players with superior risk management systems in place focus increasingly on the analysis of 'fat tails', that is, tails of the frequency distribution of returns that have higher density than what is predicted under the assumption of normality. At the same time, ALM studies and LDI techniques are being used to either monitor or hedge basic liability risks, such as interest rate risk.

Some pension fund regulators are also starting to use ALM techniques to assess the resilience of the pension fund sector to different shocks. For example, in Austria, the financial supervisory authority (FMA) has developed a scenario analysis model in order to simulate the consequences for members and beneficiaries, pension funds (Pensionskassen) and employers of different investment returns on asset classes. In the Netherlands, the pension fund supervisor $(\mathrm{DnB})$ has developed an elaborate ALM model that allows it to evaluate different regulations and model the future evolution of the sector. ${ }^{15}$ The Pensions Regulator in the United Kingdom has also made use of risk management tools in considering its regulation of the funding of pension funds.

\section{The impact of regulation and accounting on ALM for a synthetic pension fund}

Pension fund regulations aim at promoting high levels of benefit security at an acceptable cost. Accounting standards in turn aim at ensuring the transparent disclosure of information to shareholders regarding a 
company's pension obligations. This section investigates in which ways investment and risk management activities of pension funds are affected by the regulatory and accounting framework. The goal of the following analysis is to show:

- how the valuation of pension fund liabilities differs across regulatory regimes;

- how different regulatory regimes induce what is considered a "liability-optimal" investment strategy;

- the consequences of regulation on liquidity demands, funding cost, cover ratios (business accountants' measure of pension assets to liabilities), and funding levels (pension regulators' measure of pension assets to liabilities).

Some of the key variables analysed such as the funding cost and the volatility of contributions provide an order of magnitude for the potential cost of regulations. A full cost-benefit assessment of different regulatory regimes requires comparing these costs against the benefits, in terms of greater benefit security achieved. The funding level can be used as a rough proxy for benefit security, though in none of the countries studied does the value of the liabilities measured under this ratio correspond to the amount that would have to be paid to an insurance company in order to buy out the accrued benefits in case of plan termination.

In order to isolate the impact of regulations, the analysis is based on a common (synthetic) pension fund liability, which illustrates a typical situation in an OECD country. Similarly, the same stochastic economic scenarios are developed. As the goal of the exercise is to measure funding costs to plan sponsors and their volatility, it is further assumed that investment and contribution decisions are made by the plan sponsor. ${ }^{16}$ The objectives of members and beneficiaries (benefit security) are subsumed under those of the pension regulators. Under such identical plan and economic conditions, the effects of different pension regulations can be consistently compared.

The plan designs and regulations modelled in this exercise are simplifications of the real life situation. The results of the modelling exercise, therefore, cannot be used to judge the overall quality and suitability of any specific regulatory regime. The complexity of the pension context in each of these countries and, in particular, the degree of flexibility in plan design, risk sharing, and regulations do not permit a conclusive comparison of pension systems. ${ }^{17} \mathrm{~A}$ full, rigorous comparison of private pension designs is beyond the scope of this analysis. The focus is also on funding and asset regulations only. Other important regulations (such as 
OECD Working Paper on Insurance and Private Pensions

vesting and portability rules) are considered as common across all the cases considered.

\subsection{Methodology}

While there have been some studies addressing similar questions to the ones in this report, they have considered only one country-specific type of regulation. ${ }^{18}$ To our knowledge, this is the first time such a cross-country, or rather, cross-system investigation has been undertaken.

The simplified regulatory regimes considered resemble some aspects of the pension regulations in place in Germany, Japan, the Netherlands, the United Kingdom, and the United States. Our comparison includes four representative corporate DB pension plans all of which are based on the same synthetic liabilities. The valuation considered is based on traditional actuarial methods for valuing the pension liabilities. ${ }^{19}$ We consider both final pay and career average plans both with and without indexation of benefits.

The asset and investment management is modelled under consistent and rational behaviour. To avoid systematic biases, it is assumed that the pension investor applies the same Liability Driven Investment (LDI) policy based on the same, integrated ALM study incorporating the particular regulatory framework. Thus for each regulatory regime, the LDI optimal asset portfolio will be used and provides the respective best possible results under each regulation. LDI is here applied in its general meaning, which is basically a dynamic ALM.

The effects of regulatory rules are studied over a long horizon. This is achieved by applying a simulation analysis with 10000 capital market scenarios over an investment horizon of 30 years. To assess the various impacts of regulation we proceed as follows: First, we look at the specific characteristics of liabilities and the implied LDI portfolios. In a second step, the pension fund's funding situation under the particular regulation is investigated. This will provide an initial asset-liability reconciliation. Finally, the corporate sponsor's view under its International Financial Reporting Standards (IFRS) framework will be used to optimize asset allocation and contribution strategies. The model simulates the liquidity situation (cash contributions to the pension fund), the profit and loss statements (pension expenses), and ratio of pension assets to liabilities measured under IFRS (referred to as the cover ratio).

As is always the case in stochastic exercises, the methodology applied is dependent on the underlying assumptions about asset returns, and in particular about the correlations between different asset classes. We do not 
OECD Working Paper on Insurance and Private Pensions

attempt to model the implications of different tax structures, except those concerning the maximum funding level that pension funds can build without losing their tax advantages. It is also important to consider the results of such modelling as part of the broader debate about financial stability and economic development.

\subsection{Synthetic Pension Plans and Structure of Underlying Liabilities}

\section{Pension plans under investigation}

The focus of this report is on DB plans that pay out benefits in the form of annuities only. ${ }^{20}$ In order to provide a common and realistic basis for the analysis, a synthetic plan is constructed that reflects the main characteristics of prevailing plans in the countries covered in the study. We assume that lifelong annuities are paid annually beginning either at age 65 , in case of disability $^{21}$, or in case of death if there is a surviving spouse ${ }^{22}$. In order to simplify the modelling, no waiting or vesting periods are considered.

The amount of benefits depends on the type of pension plan, with a common accrual rate for all types of plans of $1 \%$ of the reference salary per year of service. Two main types of pension plans are considered: final pay and career average plans. For each of these two types of plan we consider two variations regarding indexation of benefits in payment (with and without indexation to last year's inflation ${ }^{23}$ ). The plan design details are summarised in Table 1.

Table 1. Overview of the different types of pension plans under investigation.

\begin{tabular}{llll}
\hline name & \multicolumn{1}{c}{ type of pension plan } & \multicolumn{1}{c}{ benefit accrual rate } & \multicolumn{1}{c}{$\begin{array}{c}\text { indexation of benefits in } \\
\text { payment }\end{array}$} \\
\hline FP_incr & $\begin{array}{l}\text { Final Pay Plan with } \\
\text { indexation }\end{array}$ & $\begin{array}{l}1 \% \text { of final salary per year of } \\
\text { service }\end{array}$ & $\begin{array}{l}\text { Increase based on last year's } \\
\text { inflation. }\end{array}$ \\
\hline FP_const & $\begin{array}{l}\text { Final Pay Plan without } \\
\text { indexation }\end{array}$ & $\begin{array}{l}1 \% \text { of final salary per year of } \\
\text { service }\end{array}$ & Benefits remain constant. \\
\hline CA_incr & Career Average Plan with & $\begin{array}{l}1 \% \text { of specific salary in each } \\
\text { indexation }\end{array}$ & $\begin{array}{l}\text { Increase based on last year's } \\
\text { inflation. }\end{array}$ \\
\hline CA_const & $\begin{array}{l}\text { Career Average Plan without } \\
\text { indexation }\end{array}$ & $\begin{array}{l}1 \% \text { of specific salary in each } \\
\text { year of service }\end{array}$ & Benefits remain constant. \\
\hline
\end{tabular}

To assume a realistic and representative situation we consider a corporate plan with 10,000 persons who have an existing entitlement or already receive 
OECD Working Paper on Insurance and Private Pensions

pensions. It is a synthetic group of plan members, which is mixed in respect of status (i.e. active members, old-age pensioners, disabled and widows/widowers), gender, salary and age (see Box 1).

\section{Box 1. Characteristics of plan members at the start}

At the start, the synthetic plan has the following membership composition:

- $60 \%$ active members, $25 \%$ old-age pensioners, $5 \%$ disabled and $10 \%$ widows/widowers.

- $\quad$ The gender composition is equally split between males and females.

- There are five main categories of active members according to annual salary: $1 \%$ earn 200,000 monetary units (board members), $4 \%$ earn 100,000 monetary units (upper management), $15 \%$ earn 80,000 monetary units (middle management), 20\% earn 60,000 monetary units (lower management), and $60 \%$ earn 40,000 monetary units (blue collar workers).

- The age distribution of active members mirrors the OECD average working population (see figure below), while old age pensioners, disabled and windows/widowers are equally distributed across specific age ranges (65 and 85, 45 and 64 , and 45 and 85 , respectively).

Age Distribution of Active Members

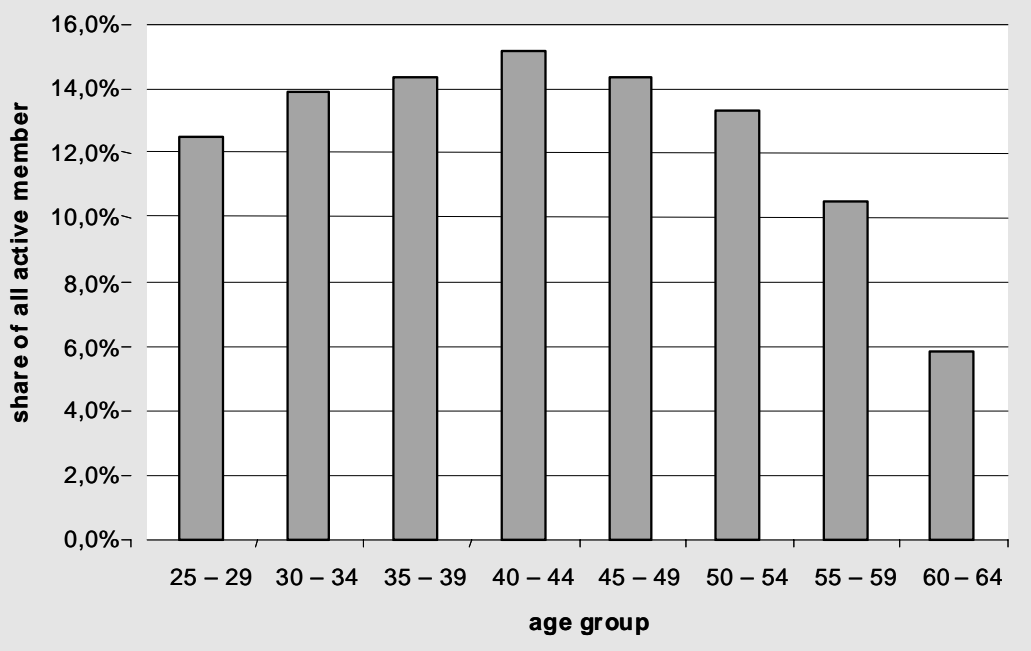

The demographic evolution of plan members is projected using mortality and morbidity assumptions normally used for occupational DB 
OECD Working Paper on Insurance and Private Pensions

plans in Germany. ${ }^{24}$ It is assumed that there are no early leavers from the plan. As the valuation of the plan's liabilities under both IFRS and regulatory methodologies includes current plan members only, the liabilities modelled do not include new entrants. The question of whether the plan is open or closed to new members is therefore irrelevant for our analysis. We also assume that salaries increase annually by productivity growth (constant factor of 1.017), by advancement in one's job or position (constant factor of $1.0025)$, and by last year's inflation, which is stochastic.

\section{Valuation of liabilities under IFRS accounting rules}

The valuation of the pension fund from the sponsor's perspective follows IFRS, and in particular standard IAS19, which addresses pension benefits. Under IAS19, pension plan liabilities, or the defined benefit obligation (DBO), are valued according to the projected unit credit method, using market yields of high quality corporate bonds (as discount rates) and estimated term of benefit obligations. Regarding mortality and morbidity, best estimate assumptions are made. ${ }^{25}$ Furthermore, the calculation includes future increases of salaries and pensions as best estimate assumptions. The valuation used also applies the option under IAS 19 for immediate recognition of actuarial gains and losses (which is the basis of the UK's FRS17 standard and a basic feature of fair value). The lack of spreading or amortisation options heightens the impact of the pension fund on the sponsor's balance sheet. $^{26}$

The sponsor's annual service cost is also calculated as per IAS 19. Service cost is primarily an accounting figure entering into the sponsors P\&L statement. Cash contributions into the pension fund are typically related to service cost but can be very different from service costs (e.g. contribution holidays). Contribution strategies are an integral part of the investment policy. A detailed specification of the contribution strategies used here will be given in the next section on investment policies.

\section{Valuation of liabilities and funding rules under different regulatory systems}

The previous section described the valuation of liabilities from the sponsor's point of view. We now characterize the valuation of liabilities from the pension fund's point of view under different regulatory regimes. Table 2 shows the main differences between the regulatory systems under investigation. A regulatory system with no specific rules apart from the prudent person principle is considered (Reg-1). The valuation of liabilities under this system follows IFRS (IAS19). The main differences in valuation across regulatory systems are driven by discount rate assumptions and 
OECD Working Paper on Insurance and Private Pensions

whether future salary and benefit increases are taken into account. Other key features of the regulatory system considered are minimum funding rules (which state recovery periods in order to reach a specific funding level) and premia paid into insolvency protection funds, which guarantee a certain level of benefits in case of bankruptcy of the plan sponsor. ${ }^{27}$

Table 2. Main characteristics of different types of modelled regulatory systems.

\begin{tabular}{|c|c|c|c|c|c|c|}
\hline \multirow{2}{*}{$\begin{array}{l}\text { Regulatory } \\
\text { system to be } \\
\text { modelled } \\
\text { Resembling }\end{array}$} & Reg-1 & Reg-2 & Reg-3 & Reg-4 & Reg-5 & Reg-6 \\
\hline & IFRS & UK & Germany & Netherlands & US & Japan \\
\hline Discount rate & \multicolumn{2}{|c|}{$\begin{array}{l}\text { depending on } \\
\text { market yields of } \\
\text { high quality } \\
\text { corporate bonds }\end{array}$} & $3.5 \%$ fixed & $\begin{array}{l}\text { current AA-swap } \\
\text { rate curve. In case } \\
\text { of indexation } \\
\text { guarantees, the } \\
\text { real market yield } \\
\text { curve. }\end{array}$ & $\begin{array}{l}\text { four year } \\
\text { average of } 30 \text { - } \\
\text { year treasury } \\
\text { bond rate }\end{array}$ & $\begin{array}{l}\text { 20-year } \\
\text { government } \\
\text { bond rate }\end{array}$ \\
\hline $\begin{array}{l}\text { Future salary } \\
\text { and pension } \\
\text { increase }\end{array}$ & \multicolumn{2}{|c|}{ taken into account } & $\begin{array}{l}\text { not taken } \\
\text { into account }\end{array}$ & $\begin{array}{l}\text { implicitly taken } \\
\text { into account if } \\
\text { revaluation and } \\
\text { indexation are } \\
\text { guaranteed } 28\end{array}$ & \multicolumn{2}{|c|}{ not taken into account } \\
\hline $\begin{array}{l}\text { Minimum } \\
\text { funding level }\end{array}$ & no & no & $104.5 \%$ & $105 \%$ & $90 \%$ & $90 \%$ \\
\hline $\begin{array}{l}\text { Additional } \\
\text { contributions } \\
\text { due to } \\
\text { minimum } \\
\text { funding rules }\end{array}$ & no & no & $\begin{array}{l}\mathrm{FL}<100 \%: \\
\text { immediate } \\
\mathrm{FL}<104 \%: 3 \\
\text { year plan }\end{array}$ & $\begin{array}{l}\mathrm{FL}<105: 1 \text { year } \\
\text { plan } \\
\text { Prob(FL>100\%)< } \\
97.5 \%: 15 \text { year } \\
\text { plan }\end{array}$ & $\begin{array}{l}\text { Additional } \\
\text { contributions if } \\
\mathrm{FL}<90 \%\end{array}$ & $\begin{array}{l}\mathrm{FL}<90 \%: 7 \\
\text { year plan }\end{array}$ \\
\hline $\begin{array}{l}\text { Legal maximum } \\
\text { funding rule }\end{array}$ & none & $105 \% 29$ & none & none & $100 \% 30$ & $150 \%{ }^{31}$ \\
\hline $\begin{array}{l}\text { Contributions } \\
\text { to Protection } \\
\text { Fund }\end{array}$ & no & yes & no & no & yes & yes \\
\hline
\end{tabular}

Note: FL is the funding level.

The models we apply capture only some of the main features of the respective national regulation systems and do not reflect very recent 
OECD Working Paper on Insurance and Private Pensions

legislative reforms, such as the new funding rules introduced in the United States as a result of the entry into force of the Pension Protection Act or the increase in the FTK recovery period from one to three years. ${ }^{32}$ Therefore, the analysis cannot be directly associated with the respective national regulation systems. We therefore refer to the modelled regulatory systems as Reg-1 to Reg-6.

In order to be able to compare contribution and investment strategies under different regulatory systems, the pension fund is endowed at the start with the same amount of assets, equal to $100 \%$ of the DBO according to Reg-1 (IAS19). Under Reg-3 to Reg-6 there is a restitution of assets to the employer at the beginning of the period so that the funding level equals a target above the minimum required by regulators. The precise target funding level chosen reflects market practice. For Reg-3, it is $110 \%$, for Reg-4 it is $120 \%$, and for Reg-5 and Reg-6 it is $100 \%$ of the regulatory DBO. ${ }^{33}$ At the end of the modelling period, the funding shortfall relative to the IAS19 DBO measure of liabilities is covered via a lump-sum payment by the plan sponsor. Hence, under all regulatory regimes, the start and end period endowments are exactly the same.

\section{DBO projections}

Figure 1 to 4 show the evolution of the DBO for the four different types of plan calculated according to the valuation methods under the different regulatory systems. A range of value of liabilities is provided around a central best estimate, the variability being determined by the stochastic future development of inflation and discount rates. The range of outcomes is assigned different levels of likelihood, each indicated by a different coloured bar. For example, liability valuations within the dark grey bar have a $50 \%$ probability of occurring. In all cases, the DBO projection is shown at its current level (2006), and two future dates (2015 and 2030).

For the period considered, the DBO rises gradually as a result of salary growth. Over a longer period, however, the DBO declines as the impact of death of members and beneficiaries overrides that of salary growth. This can be observed in Figure 5, which plot the evolution of the DBO in a deterministic setting (central best estimate) for the final pay plan with indexation under Reg-1.

The differences in DBO between the different types of plan are substantial under Reg-1, Reg-2 and Reg-4. Under these regimes, the DBO of the career average plan without indexation (Figure 4) is about half of that of the final pay plan with indexation throughout the first 24 years of the simulation period, 2006-2030 (Figure 1). In the other regulatory regimes, the differences in DBO between the different types of plan are much smaller, 
OECD Working Paper on Insurance and Private Pensions

mainly because indexation is not taken into account in the regulatory measure of the DBO.

The differences in measures of liabilities (DBOs) for a given plan type are driven by two main parameters, namely the choice of discount rate and the extent to which salary revaluation and benefit indexation factors are taken into account. For example, in the case of the final salary plan with indexation (Figure 1), the central best estimate of the current liability valued with the Reg-6 rules (576) is only about $60 \%$ of the liability applying Reg-1 rules (925). On the other hand, for the career average plan with indexation (Figure 3), the central best estimate of current liability valued under Reg-6 rules (486) is $75 \%$ of that using Reg-1 rules (642). By moving from a final salary to a career average plan, therefore, differences in valuations across regulatory regimes are diminished.

The removal of indexation causes yet greater convergence in DBO measures (see Figures 2 and 4). Moreover, the highest central estimate of liabilities in both plans without indexation (final pay and career average) is the one using Reg-3 valuation rules rather than the one using Reg-1 ones as a result of the lower discount rate used. 
OECD Working Paper on Insurance and Private Pensions

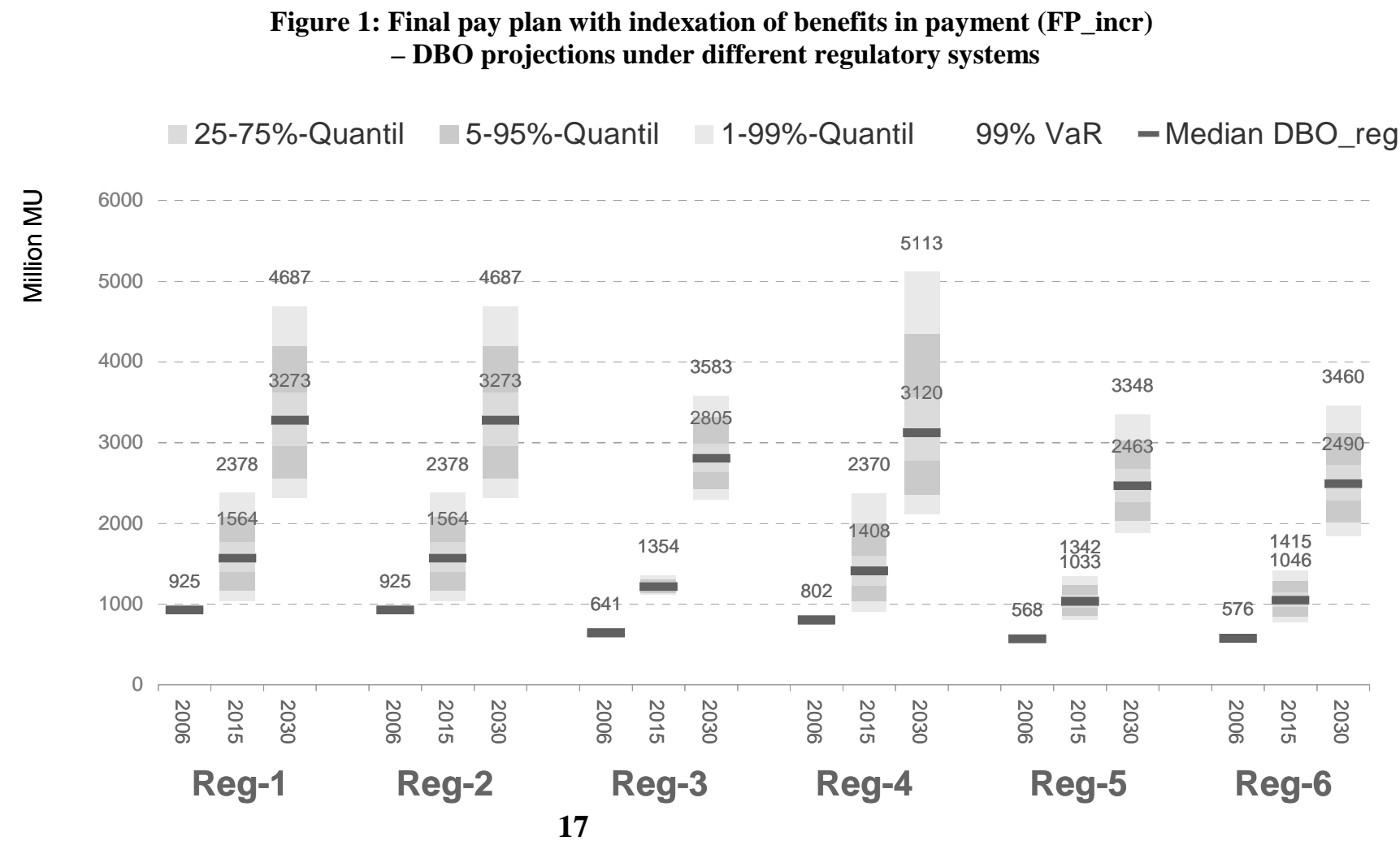


OECD Working Paper on Insurance and Private Pensions

Figure 2: Final pay plan without indexation of benefits in payment (FP_const) - DBO projections under different regulatory systems

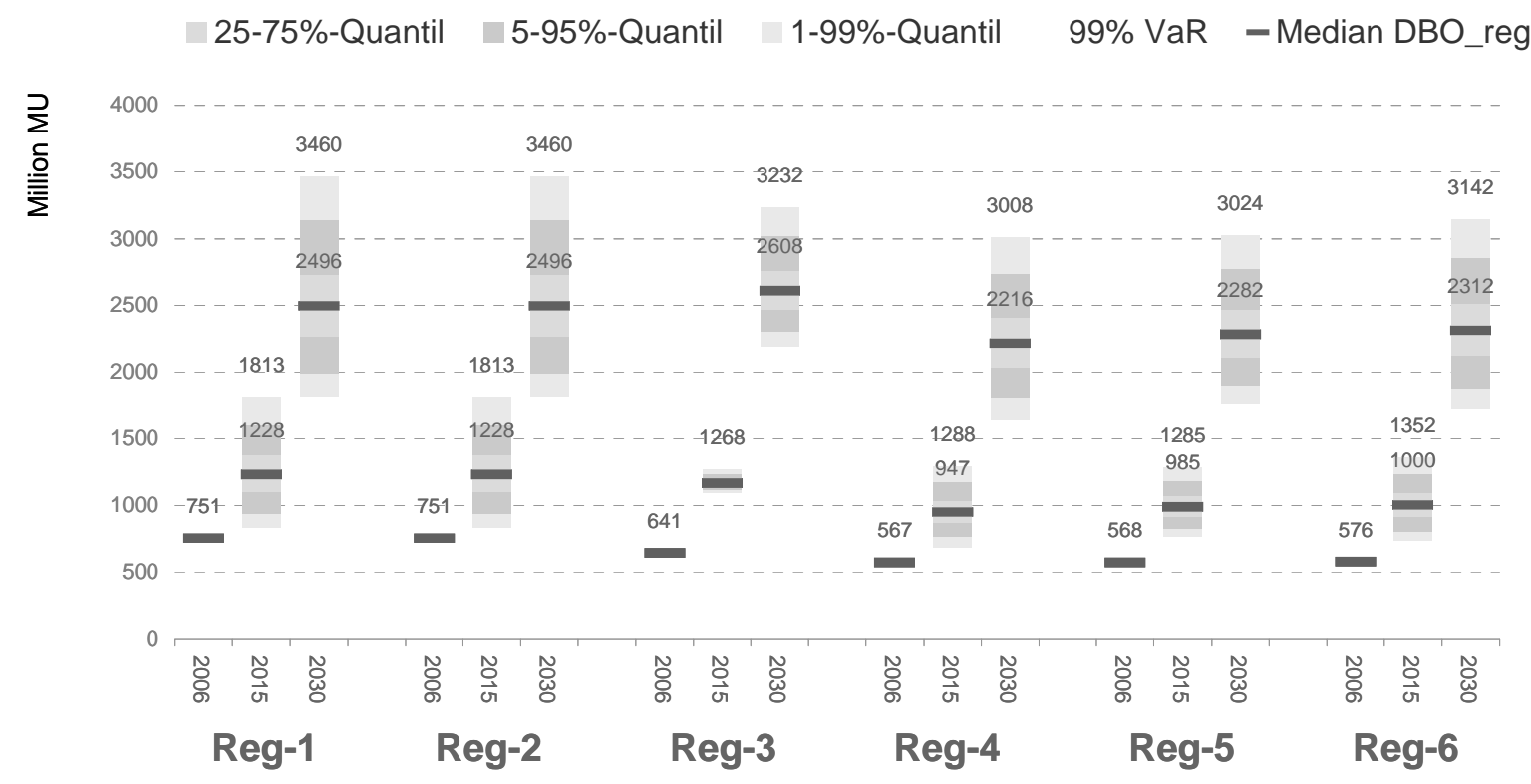


OECD Working Paper on Insurance and Private Pensions

Figure 3: Career average plan with indexation of benefits in payment (CA_incr) - DBO projections under different regulatory systems

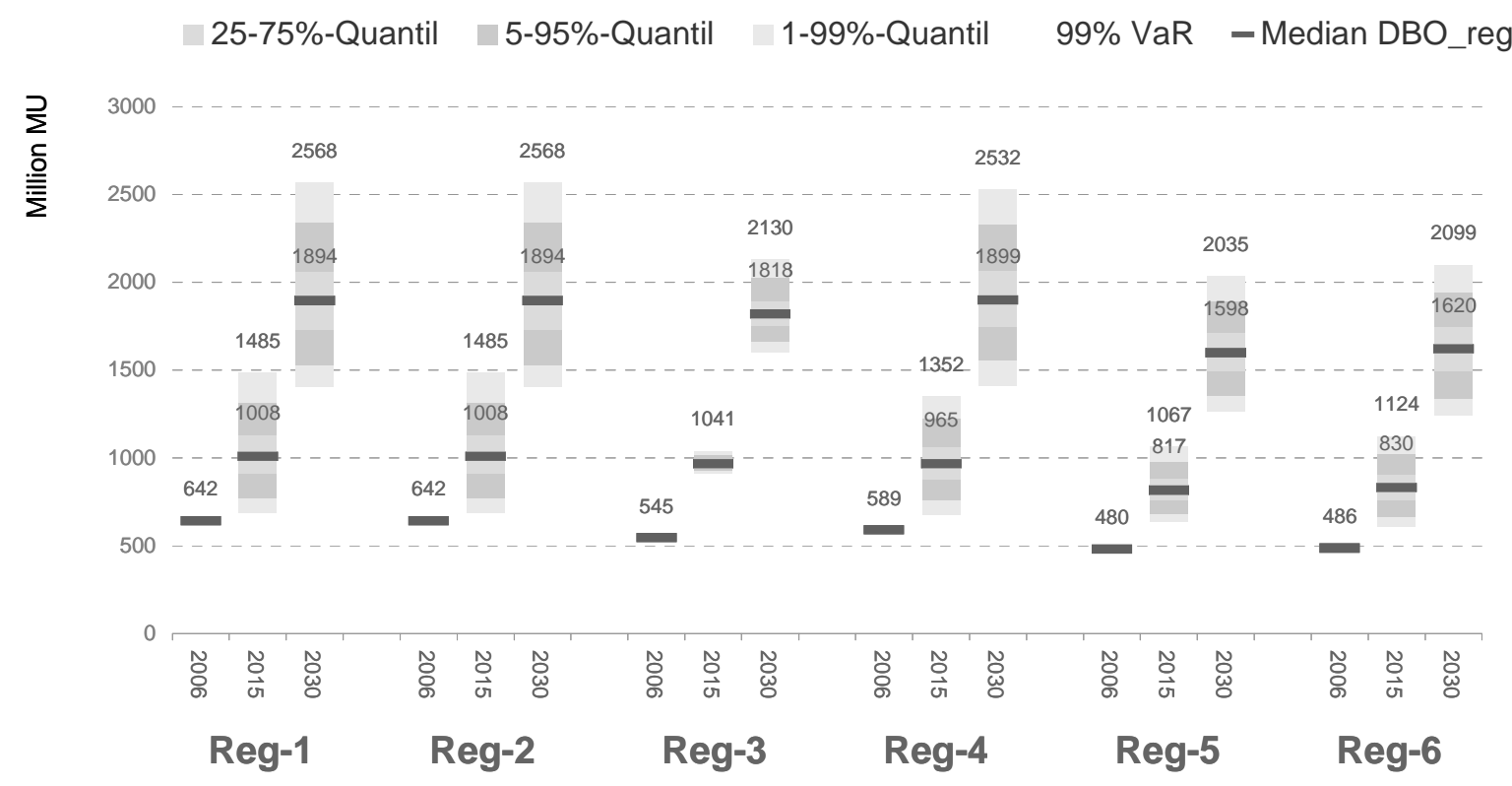


OECD Working Paper on Insurance and Private Pensions

Figure 4: Career average plan without indexation of benefits in payment (CA_const) - DBO projections under different regulatory systems

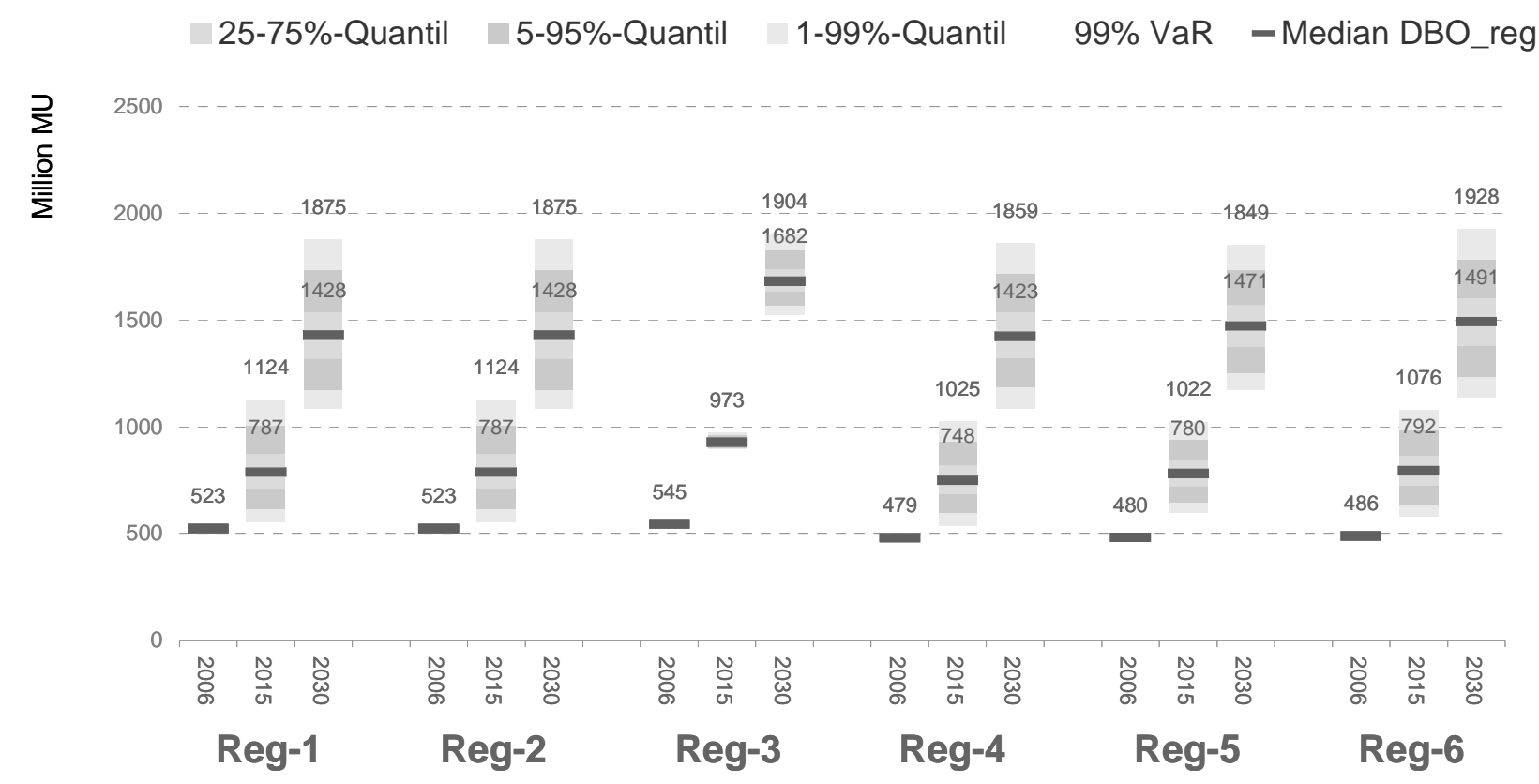


OECD Working Paper on Insurance and Private Pensions

Figure 5. Deterministic projection of DBOs over 80 years for the final pay pension plan with indexation under IAS19 (Reg-1).

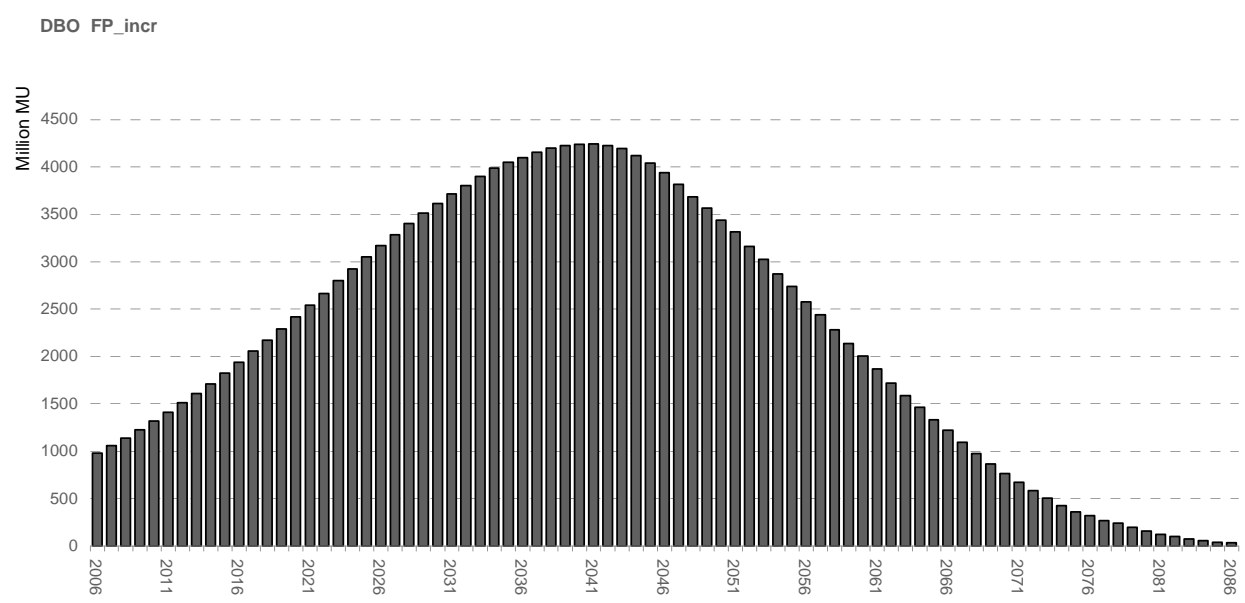

\subsection{Liability based Investment Philosophy}

\section{The ALM Framework}

The ALM framework is based on a surplus optimization approach. The process starts with a systematic assessment of the stochastic characteristics of the underlying liabilities and their sensitivities to all relevant risk factors. These risk factors, such as inflation, the term structure of interest rate, and the growth rates of salaries, need to be modelled individually and consistently. Based on a set of different scenarios of possible future economic environments ${ }^{34}$, a consistent stochastic description of liabilities can be given. This stochastic modelling of liability behaviour goes beyond the traditional actuarial modelling with deterministic expected cash flows. In a stochastic framework, the statistical properties of the liabilities, such as volatility and duration (sensitivity to interest rates), are key factors driving the asset allocation decision. The regulatory systems considered, as they determine the measures of the liabilities, are therefore expected to affect the investment strategy. Table 3 shows the statistical properties of the liabilities in a final pay plan with indexation under the different regulatory frameworks Reg-1 to Reg-6. The highest volatility and highest duration of 
OECD Working Paper on Insurance and Private Pensions

liabilities are those measured under Reg-1 and Reg-2. The duration of the liabilities under Reg-3 is zero, because of the use of a fixed discount rate. The liabilities also grow faster under Reg-3 to Reg-6 than under Reg-1 or Reg- 2 because the latter incorporate salary increases from the start, whereas these adjustments are only progressively incorporated into the other measures of liabilities.

Table 3. Statistical properties of liabilities of the four types of pension plans under different regulatory regimes.

\begin{tabular}{|c|c|c|c|c|c|c|c|c|c|c|c|c|}
\hline & \multicolumn{3}{|c|}{ FP_incr } & \multicolumn{3}{|c|}{ FP_const } & \multicolumn{3}{|c|}{ CA_incr } & \multicolumn{3}{|c|}{ CA_const } \\
\hline & $\begin{array}{l}\text { DBO } \\
\text { RoR }\end{array}$ & $\begin{array}{c}\text { Vola DBO } \\
\text { RoR }\end{array}$ & $\begin{array}{c}\text { Interest rate } \\
\text { sensitivity }\end{array}$ & $\begin{array}{l}\text { DBO } \\
\text { RoR }\end{array}$ & $\begin{array}{c}\text { Vola DBO } \\
\text { RoR }\end{array}$ & $\begin{array}{c}\text { Interest } \\
\text { rate } \\
\text { sensitivity }\end{array}$ & DBO RoR & $\left|\begin{array}{c}\text { Vola DBO } \\
\text { RoR }\end{array}\right|$ & $\begin{array}{c}\text { Interest rate } \\
\text { sensitivity }\end{array}$ & $\begin{array}{l}\text { DBO } \\
\text { RoR }\end{array}$ & $\begin{array}{c}\text { Vola DBO } \\
\text { RoR }\end{array}$ & $\begin{array}{l}\text { Interest } \\
\text { rate } \\
\text { sensitivity }\end{array}$ \\
\hline Reg-1 & $5.0 \%$ & $15.2 \%$ & 21.0 & $4.9 \%$ & $14.3 \%$ & 20.7 & $5 \%$ & $14.0 \%$ & 20.4 & $4.3 \%$ & $13.2 \%$ & 19.8 \\
\hline Reg-2 & $5.0 \%$ & $15.2 \%$ & 21.9 & $4.9 \%$ & $14.3 \%$ & 20.7 & $4.9 \%$ & $14.0 \%$ & 20.4 & $4.3 \%$ & $13.2 \%$ & 19.8 \\
\hline Reg-3 & $6.7 \%$ & $0.7 \%$ & - & $6.0 \%$ & $0.5 \%$ & - & $5.4 \%$ & $0.5 \%$ & - & $4.5 \%$ & $0.2 \%$ & \\
\hline Reg-4 & $6.3 \%$ & $15.2 \%$ & 16.1 & $7.0 \%$ & $11.4 \%$ & 14.2 & $5.0 \%$ & $15.6 \%$ & 16.6 & $5.2 \%$ & $11.6 \%$ & 14.9 \\
\hline Reg-5 & $7.3 \%$ & $4.1 \%$ & 4.0 & $6.6 \%$ & $4.1 \%$ & 4.0 & $6.0 \%$ & $4.2 \%$ & 4.1 & $4.9 \%$ & $4.1 \%$ & 4.6 \\
\hline $\operatorname{Reg}-6$ & $7.7 \%$ & $10.4 \%$ & 16.6 & $6.9 \%$ & $10.5 \%$ & 17.0 & $6.4 \%$ & $10.6 \%$ & 17.1 & $5.3 \%$ & $10.7 \%$ & 18.0 \\
\hline
\end{tabular}

Note: DBO RoR is the growth rate of DBO (Rate of Return ), Vola DBO RoR is the volatility of the growth rate of DBO. The interest rate sensitivity is measured as the duration of the surplus risk minimising portfolio with respect to the regulatory DBO.

The identification of a liability benchmark serves as a first orientation of the characteristics needed on the asset side. The number of possible investment strategies is indefinite. However, rational behaviour suggests using efficient portfolios only, that is, those that are not dominated by others with respect to their risk-return characteristics. The portfolio efficiency frontier considered is one that offers the best possible trade off between the mean excess return of the pension fund's assets over the growth of the liabilities and the volatility of this excess return. Based on its specific goals (like minimizing the expected net funding cost of the pension plan), risk preferences and other constraints, the corporate sponsor would choose one of those investment portfolios in the efficiency frontier as his strategic asset allocation (SAA-LDI). In case of a dynamic strategy (DSP-LDI ${ }^{35}$ ) the sponsor would additionally formalise a management rule of when to switch from one of the risk efficient portfolios to another.

When considering the choice of investment portfolio, the prudent person requirement is interpreted as using risk-efficient and well-diversified portfolios. Risk in the ALM framework measures the deviation with respect to a liability-hedging portfolio, where the liability is the DBO calculated under each regulatory regime. The surplus return, meanwhile, is the excess return obtained on the assets above the rate of growth of the liabilities. The surplus risk-return efficiency frontier can hence be calculated under each 
regulatory regime, as shown in Figure 6a for the final salary plan with indexation (FP_incr) and in Figure $6 \mathrm{~b}$ for the career average plan with indexation. Each of the lowest surplus risk portfolios represents the "mismatch minimising portfolio". This portfolio tries to replicate the stochastic nature of the respective liabilities as well as possible given the universe of assets available. The mean excess return of the mismatch minimising portfolios is negative in cases Reg- 2 to Reg-6 because the growth of the liabilities (the compounded effect of interest cost and salary growth) is greater than the return on low risk assets.

If the pension fund is also subject to a specific type of quantitative investment regulation (only the case in Reg-3) then regulatory requirements may override the sponsor's primary choice of investment strategy. The portfolios under the shaded area on the efficiency curve of Reg-3 are not feasible because of regulatory limits on risky strategic asset allocations. These portfolios are therefore excluded from the optimization process.

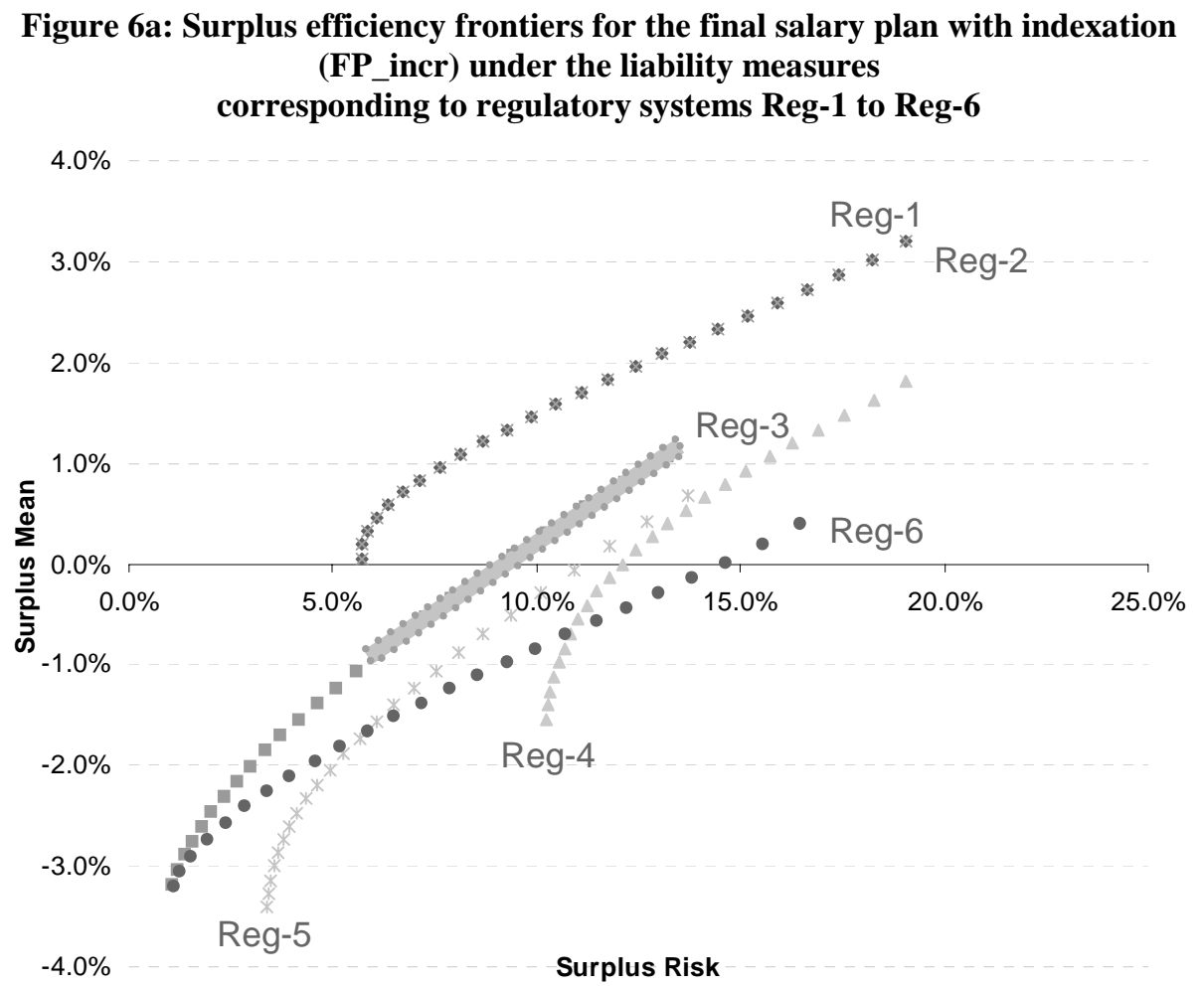




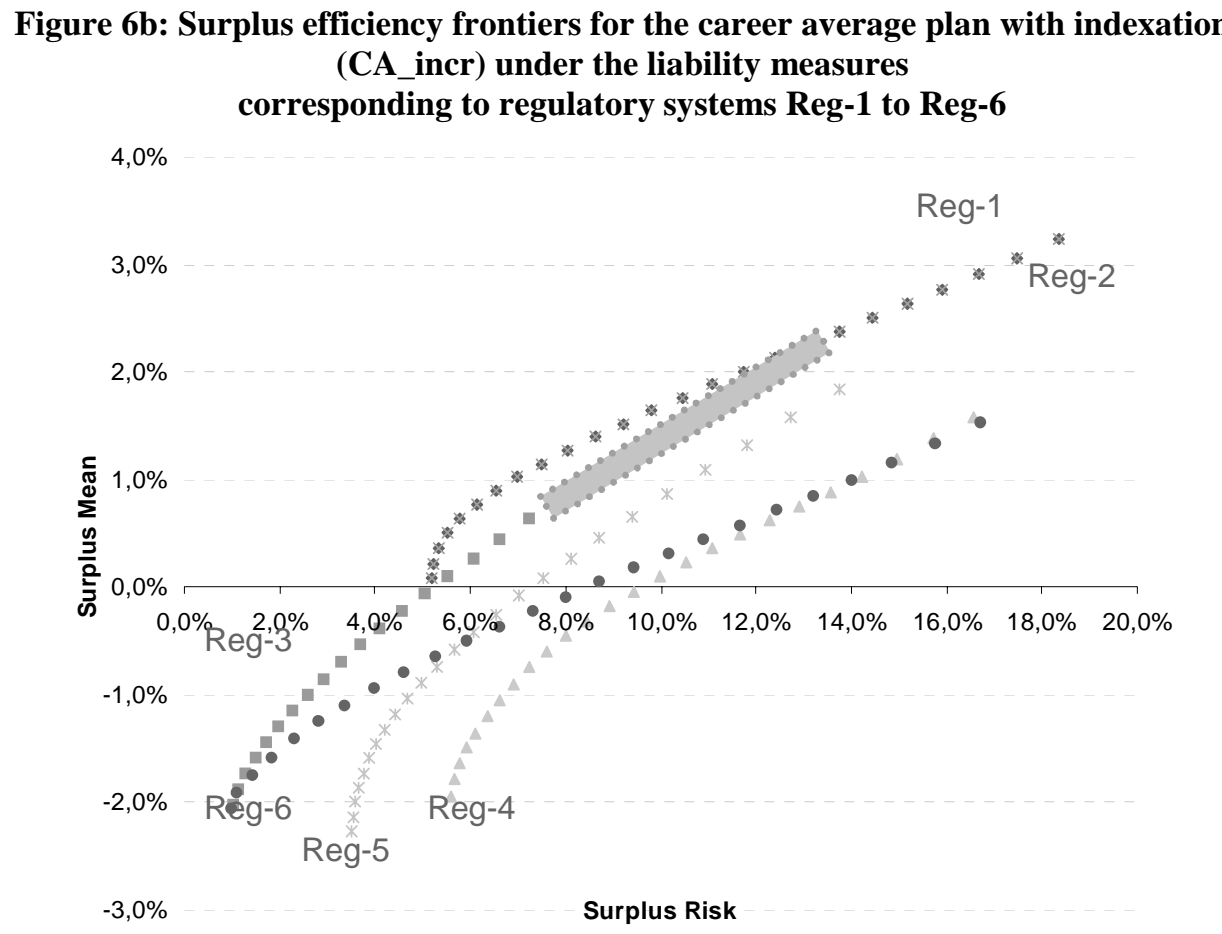

All portfolio allocations are "well-diversified" over various asset classes such as government and inflation linked bonds (with different maturities up to 30 years), corporate bonds, international stocks, real estate and absolute return funds. ${ }^{36}$ However, due to the different characteristics of the underlying liabilities (i.e. their sensitivity with respect to interest rates ${ }^{37}$ and inflation) for different regulatory regimes the portfolios on these riskefficient frontiers can be substantially different. For example, the mismatch minimising portfolio has a zero duration under Reg-3, but 22 years under Reg-1 and Reg-2. Portfolios for Reg-3 regulation try to establish an absolute return type of investment. They hold a high proportion in alternative investments to match as well as possible biometric risks as hedging instruments are not available (6\% in real estate and absolute return funds in the mismatch minimising portfolio). Bond investments consist primarily of inflation-linked instruments since this is the only remaining sensitivity to address.

The contribution strategy is the other main parameter driving the ALM. In the IFRS context, the corporate sponsor has a large degree of freedom of when to fund pension liabilities and in what amount. Unfunded liabilities need to be shown on the balance sheet and might influence the credit rating and re-financing costs of the company. Accounting standards, therefore, can 
OECD Working Paper on Insurance and Private Pensions

provide an incentive to sponsoring companies to fully fund their pension plans. Regulators also impose funding requirements on pension funds, though these are usually based on the regulatory DBO that often exclude the impact of salary projections.

In order to make comparisons between the different regulatory regimes, we model the same contribution strategies (funding policy). All strategies consist of a lower funding level, an upper funding level, and a withdraw level, as the example in Figure 7 shows. The corporate sponsor's contribution strategy is entirely determined by the current funding level. If the funding level is below the critical threshold of "lower level" the amount of contributions is set above the regular service costs so that the "lower level" is reached within a certain recovery period of, for example, 10 years. When the funding level is between the lower and upper threshold, contributions equal the amount of regular service costs. For situations when the funding level is above the "upper level" the mechanism assumes contribution holidays and no cash contributions flow into the pension fund. In cases of substantial over-funding the policy allows restitutions to the corporate sponsor in order to bring back the funding level back to a withdraw level.

Figure 7: Basic action mechanism of a contribution strategy.

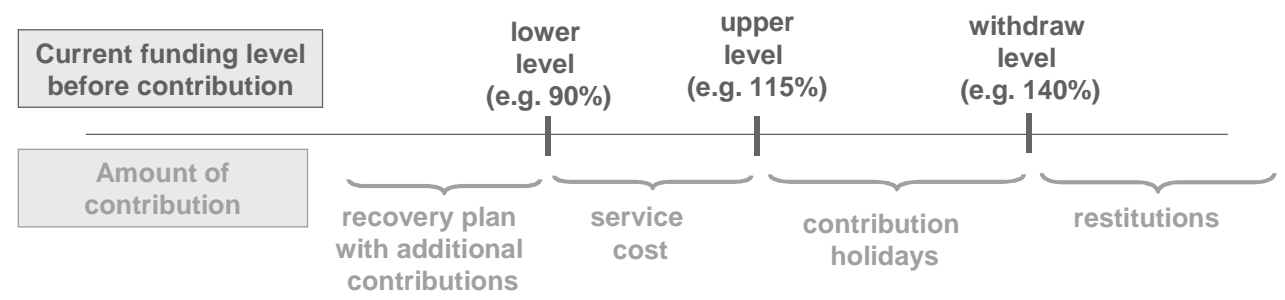

Since different funding policies chosen by the sponsor induce different liquidity demands, the choice of the contribution strategy will be identified within the ALM optimisation framework. For simplicity, we consider a set of seven alternative contribution strategies, shown in Table 4. The funding levels under each strategy are defined according to the DBO measure of the regulatory system considered. 
OECD Working Paper on Insurance and Private Pensions

Table 4. Contribution strategies under investigation.

\begin{tabular}{|c|c|c|c|c|}
\hline ContributionStrategy Basic & \\
\hline ID & lower_level & upper_level & Withdraw_level & RecPlan \\
\hline 1 & $70 \%$ & $90 \%$ & $140 \%$ & 10 \\
\hline 2 & $70 \%$ & $95 \%$ & $140 \%$ & 10 \\
\hline 3 & $80 \%$ & $100 \%$ & $140 \%$ & 10 \\
\hline 4 & $90 \%$ & $105 \%$ & $140 \%$ & 10 \\
\hline 5 & $95 \%$ & $110 \%$ & $140 \%$ & 10 \\
\hline 6 & $100 \%$ & $115 \%$ & $140 \%$ & 10 \\
\hline 7 & $100 \%$ & $120 \%$ & $140 \%$ & 10 \\
\hline
\end{tabular}

Funding regulations set an additional constraint on the sponsor's contribution policy. Table 2 shows the funding and contribution requirements set by different regulatory regimes. The strategically intended corporate funding rule (as described in Table 4) can therefore be overridden by regulatory requirements and additional contributions might be necessary. The amount of additional contributions depends on the type of regulatory system.

\section{Deriving optimal strategic asset allocations and contribution strategies}

The optimal ALM strategy for the corporate sponsor consists of a combination of an asset allocation and a corresponding contribution strategy. The corporate sponsor's preferred combination of asset portfolio and contribution strategy would be derived for example by solving the following (stylised) type of optimisation problem:

-- Minimise the expected Net Funding Cost (NFC) of the given pension plan subject to a set of sponsor specific risk constraints, such as

- (Liquidity) Avoid extreme cash requests in a single period, and, over the entire investment period, keep total excess contributions low.

- (Profit \& Loss Statement) Avoid extremely high pension expenses.

- (Balance Sheet) Avoid extreme shocks to the cover ratio.

- (Investment) The investment portfolio has to comply with asset regulations or quantitative asset limits.

- (Solvency) The contribution strategy has to comply with funding regulations requirements.

For the goal function we use "Net Funding Costs" (NFC). This is in line with earlier studies on dynamic ALM modelling for DB pension funds. ${ }^{38}$ 


\section{OECD Working Paper on Insurance and Private Pensions}

More recently, some models have applied utility functions ${ }^{39}$, but given the different governance structures and therefore different patterns of influence for the stakeholders in the analysed countries, formulating one utility function that can be applied for all countries was not regarded as feasible. The NFC function used characterises the economic value needed to ensure that at the end of the considered investment horizon (i.e. in 30 years) the funding level is again at $100 \%$, assuming that we started at a $100 \%$ funding level at time $t=0$. Contributions into the pension fund mean cash outflows for the corporate sponsor. The (expected) net funding cost therefore comprises all cash outflows the sponsor has to put into the fund - either due to his own funding preferences or imposed by regulatory funding

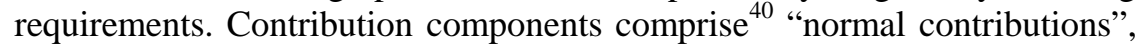
"additional contributions" and for some systems also "protection fund contributions". Negative contributions, which would mean a cash inflow would be "restitutions from the fund to the sponsor" in cases, the fund has a substantial over-funding. ${ }^{41}$ Taking the promised, accrued benefits as given, the corporate sponsor's goal is to implement the best possible investment and contribution strategy so that the net funding cost is as small as possible.

Investment strategies with "higher surplus returns" provide lower net funding costs on average but go along with a more volatile annual funding cost and larger swings in the cover ratio. These risks need to be taken into account when choosing the contribution and investment strategy. ${ }^{42}$ The risks are limited by the constraints imposed on cash requests, the cover ratio and pension expenses reported in the sponsor's profit \& loss account. Hence, the contribution and investment strategy is driven by the IFRS accounting framework. This case study considers three different sponsors. A "High Risk Tolerance", a "Medium Risk Tolerance" and a "Low Risk Tolerance" sponsor, that tries to match his liabilities as well as possible (LDI-matching). In this study, risk is not endogenous as in the case of applying state prices ${ }^{43}$ but conceptualised as adverse development for the key variables which have to be explicitly taken into account.

Based on an integrated and comprehensive simulation analysis ${ }^{44}$ for all combinations of asset allocations and contribution strategies the resulting consequences on liabilities, assets, funding status, contributions, pension expenses, etc., for the pension fund are projected into the future. This is done separately for all regulatory regimes. With these simulation results, the optimisation problem can be solved directly by selecting the combination with the minimal NFC among all feasible combinations. 
OECD Working Paper on Insurance and Private Pensions

\subsection{Comparing the Impact of Regulation}

Regulations act at different levels, changing the profile of cash contributions and hence affecting the sponsor's liquidity and its investment strategy. As under each regulatory regime there is a different funding target, the funding cost will also necessarily differ. Ultimately, the impact of regulations can be assessed by comparing the net funding cost against the resulting funding levels and cover ratios. From the sponsor's perspective the key objective is minimising the net funding cost taking benefits as given. From the regulator's perspective, this cost must be traded off against the extra security afforded to the pension fund in the form of higher funding levels.

\section{Impact on Contributions and Corporate Sponsor's Liquidity Situation}

Liquidity aspects are crucial for the company's investment policy. Especially, high demands on cash contributions in a single year can cause financial distress to the sponsor and must be avoided. Figure $8 \mathrm{a}$ and $8 \mathrm{~b}$ provide a detailed view on additional contributions for the final pay and career average plans with indexation. ${ }^{45}$ Additional contributions are mainly triggered by regulatory requirements such as recovery plans. 
OECD Working Paper on Insurance and Private Pensions

Figure 8a: Percentile plots of cash contributions in selected years for different regulations in a final pay plan with indexation (FP_incr) for the High Risk Tolerance sponsor

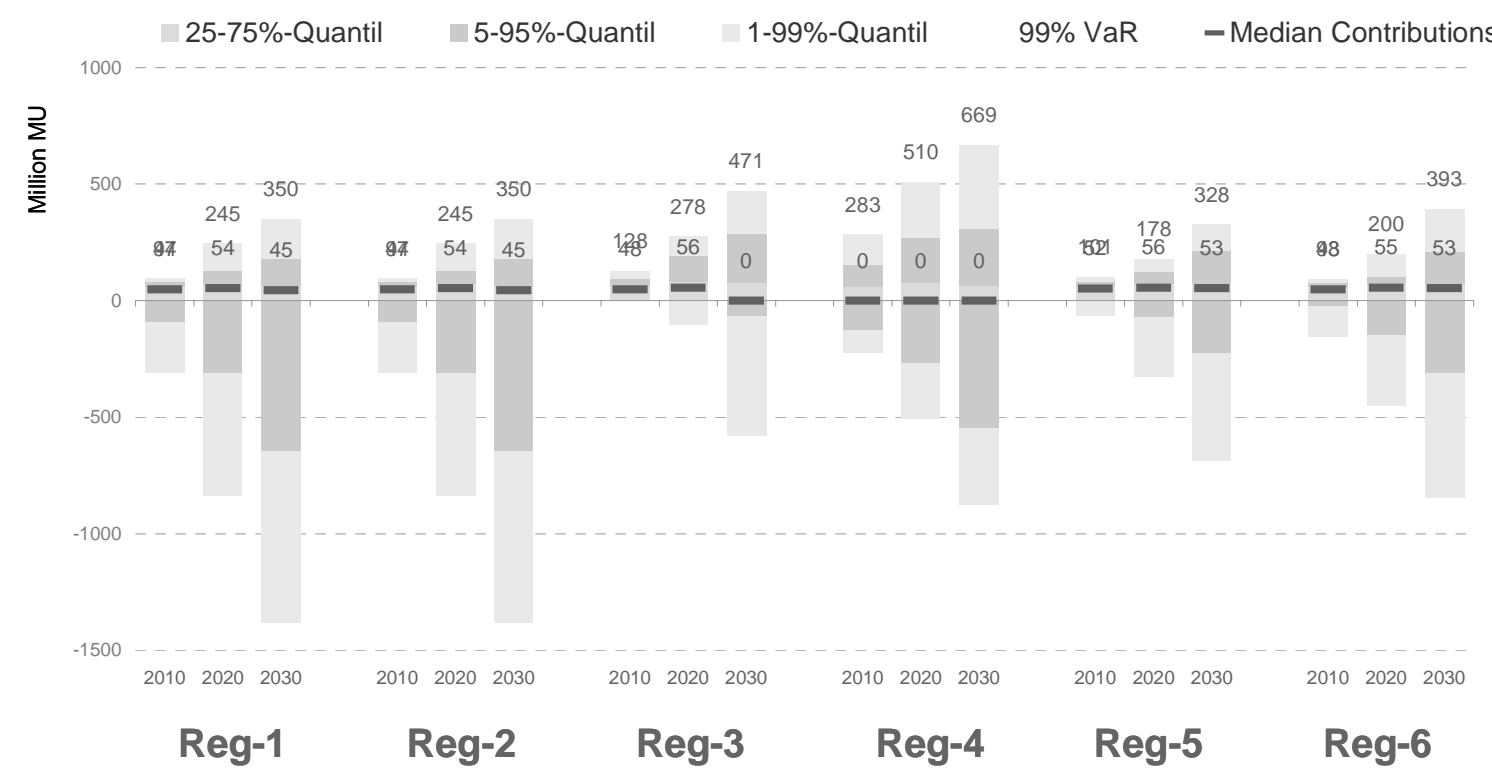


OECD Working Paper on Insurance and Private Pensions

Figure 8b: Percentile plots of cash contributions in selected years for different regulations in a career average plan with indexation (CA_incr) for the High Risk Tolerance sponsor

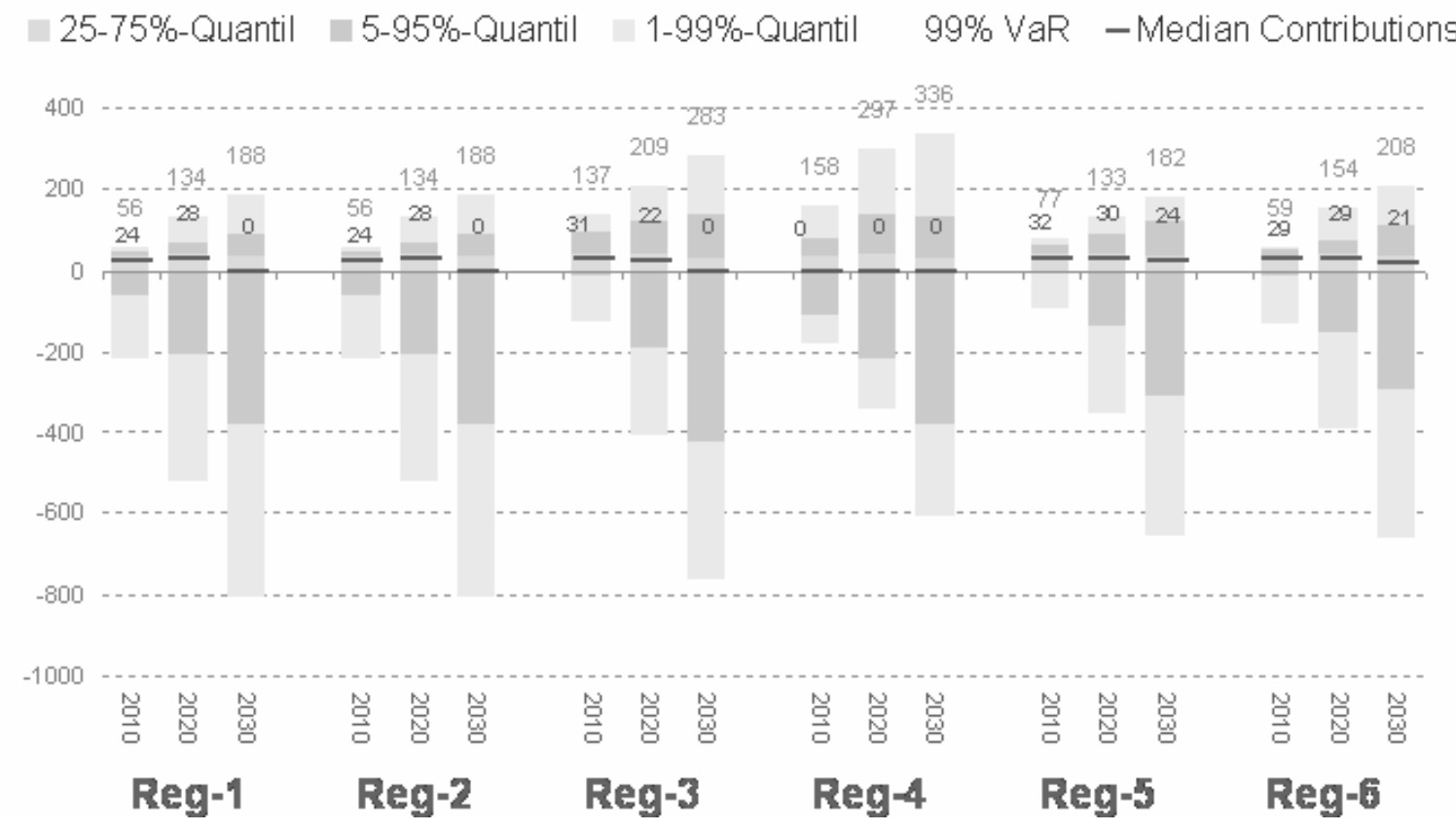


OECD Working Paper on Insurance and Private Pensions

Regulations influence the optimal choice of an investment policy by affecting the liquidity constraints. Regulation systems (like Reg-3 and Reg-4) with strict solvency rules on the funding level (100 percent for Reg-3 and 105 percent for Reg-4, respectively) in combination with very short recovery plan periods (immediately for Reg-3, or 1 year for Reg-4, respectively) cause much higher demand on liquidity. Systems with longer recovery periods (like Reg-5 and Reg-6) or those without explicit recovery periods (like Reg-1, or Reg-2) provide more flexibility. Ad-hoc liquidity demand is much smaller since the additional funding can be spread over several years.

\section{Impact on cover ratios and funding levels}

Two main measures of the funding status of pension funds are considered. The funding level is defined as the ratio of assets and liabilities from the pension fund's point of view, using the methodology required by pension regulators. The cover ratio is defined as the ratio of assets and liabilities from the plan sponsor's point of view, measured under accounting standard IAS 19 (IFRS, as under Reg-1).

The corporate sponsor wants to avoid disturbances in its financial statements triggered by the pension fund for its reports to investors. Both the absolute level of the cover ratio and its volatility are important in this regard. The different volumes of DBOs given by different regulation regimes (for the same pension plan) lead to substantially different funding situations (cover ratios) from the corporate balance sheet view. From the regulator's (and beneficiary's) point of view, on the other hand, the relevant measure of solvency is the funding level, measured under the specific valuation rules of the regulatory system in place.

Figure $9 \mathrm{a}$ and $9 \mathrm{~b}$ illustrate the funding situation for selected years from the view of the sponsor (the cover ratio) for the final pay plan with indexation (FP_incr) and the career average plan with indexation (CA_incr), respectively. For the final pay plan, the highest cover ratios are achieved under Reg-1 and Reg-2, because sponsors face no regulatory constraints on their funding and focus on the impact of the net pension liability on their balance sheet, as well as Reg-4, a regulatory system requires the use of real interest rates to calculate the DBO measure. In the other cases, funding regulations override balance sheet considerations, so pension funds end up with a cover ratio (measured under IAS19) that is substantially below $100 \%$. For the career average plan with indexation, Reg-3 also leads to higher cover ratios than under Reg-1 and Reg-2, as a result of the lower (fixed) discount rate used (see Figure 9b). 
OECD Working Paper on Insurance and Private Pensions

Figure 9a: Percentile plots of Cover Ratio under different regulations for the final pay plan with indexation (FP_incr) for the "High Risk Tolerance" sponsor

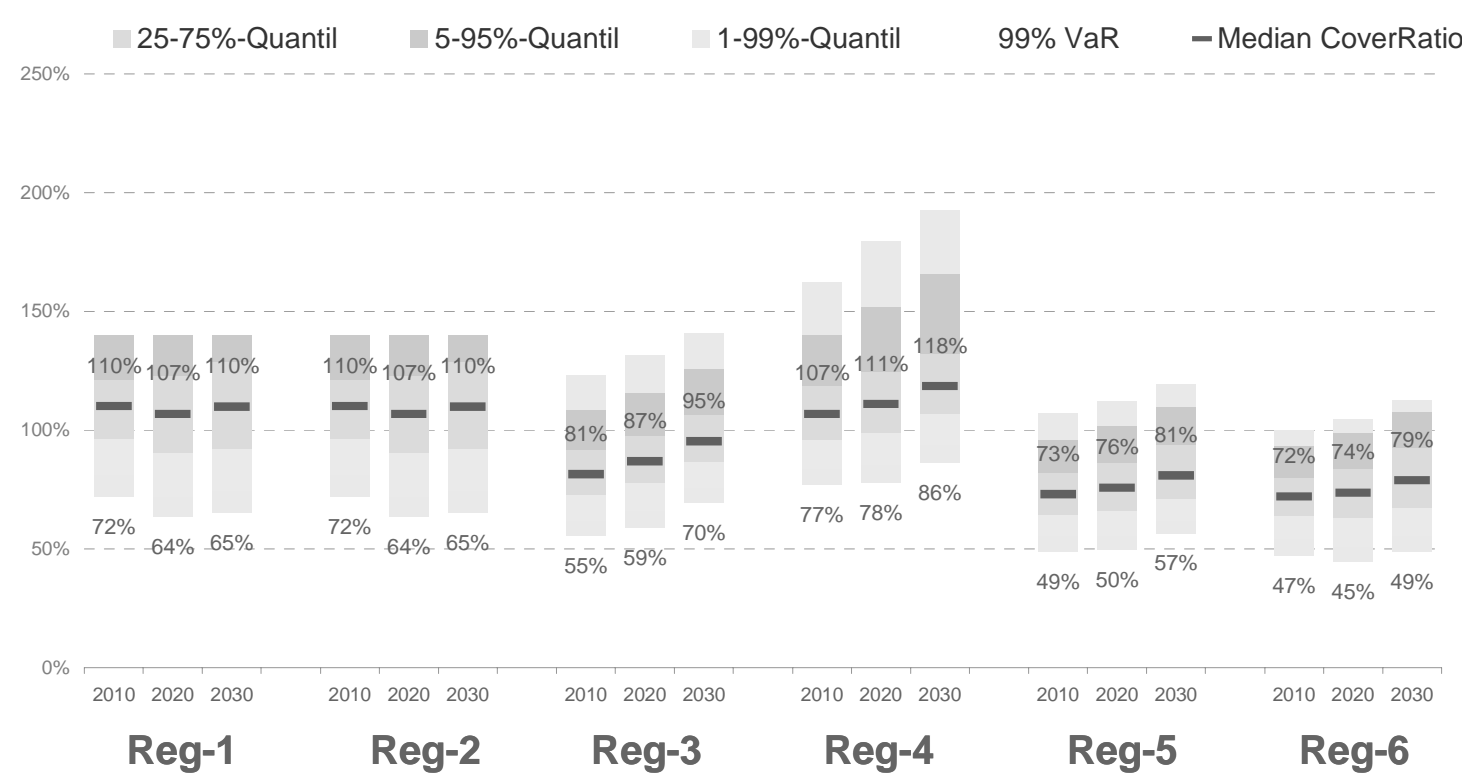


OECD Working Paper on Insurance and Private Pensions

Figure 9b: Percentile plots of Cover Ratio under different regulations for the career average plan with indexation (CA_incr) for the "High Risk Tolerance" sponsor

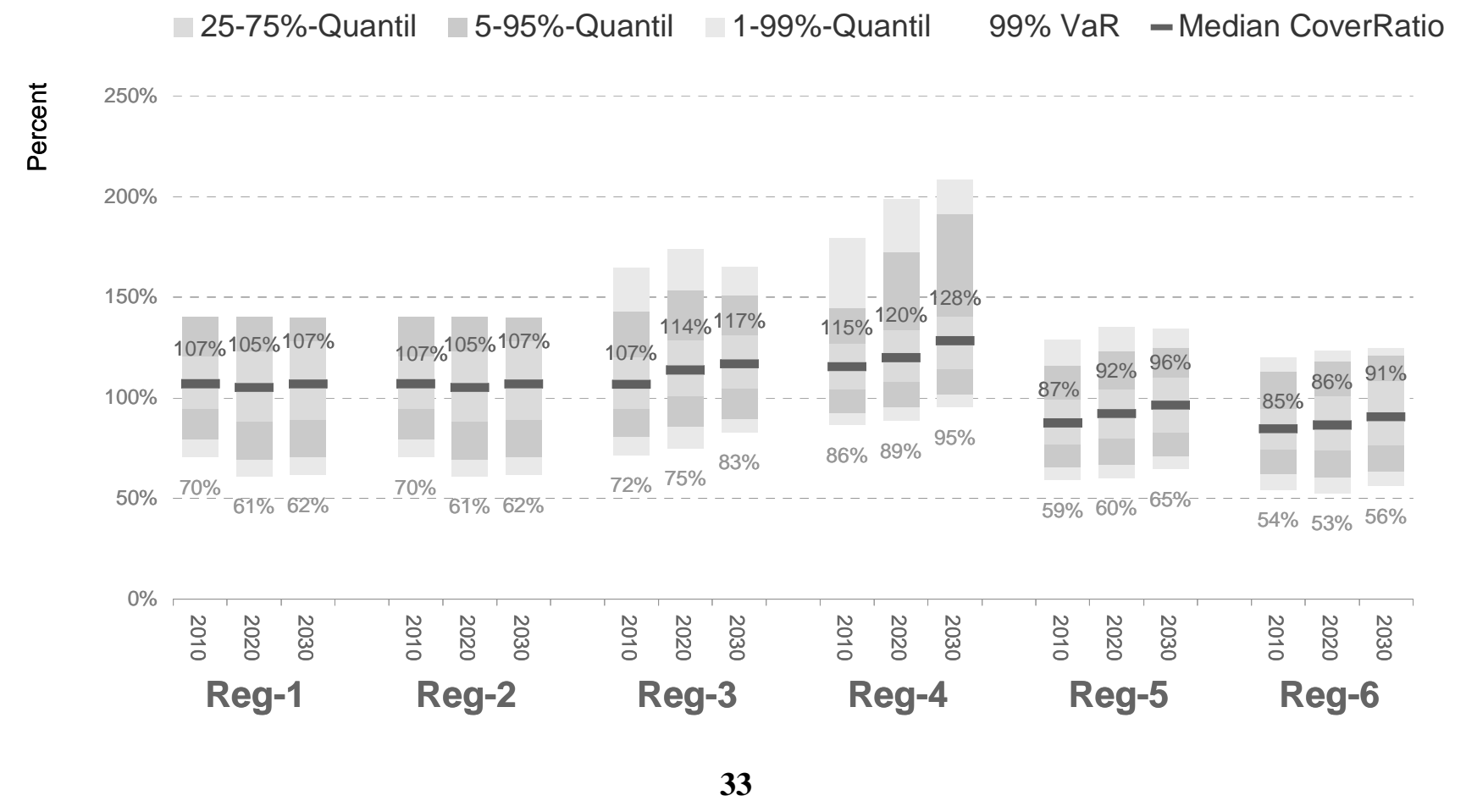


OECD Working Paper on Insurance and Private Pensions

Figure 10a: Percentile plots of regulatory Funding Levels for different regulation (FP_incr) for the "High Risk Tolerance" sponsor

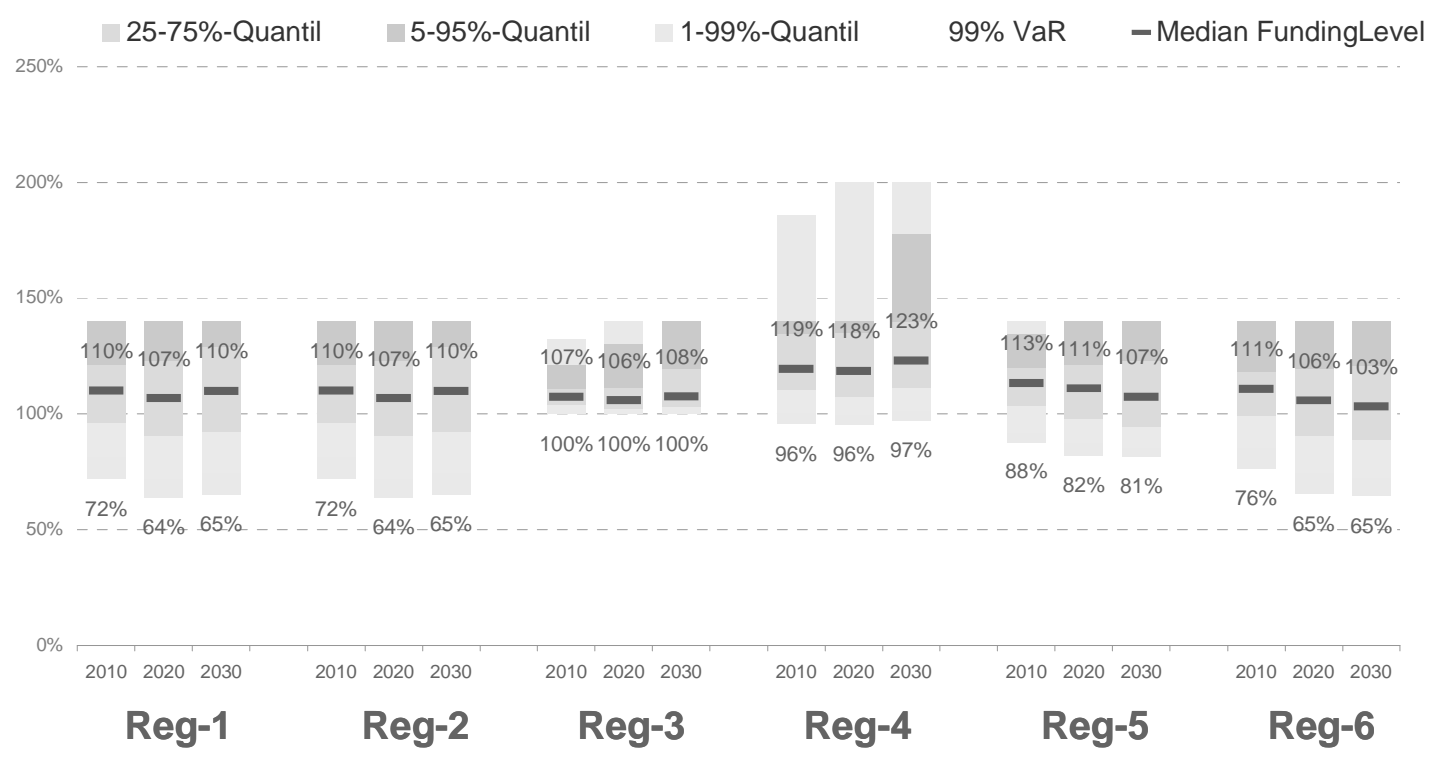


OECD Working Paper on Insurance and Private Pensions

Figure 10b: Percentile plots of regulatory Funding Levels for different regulation (CA_incr) for the "High Risk Tolerance" sponsor

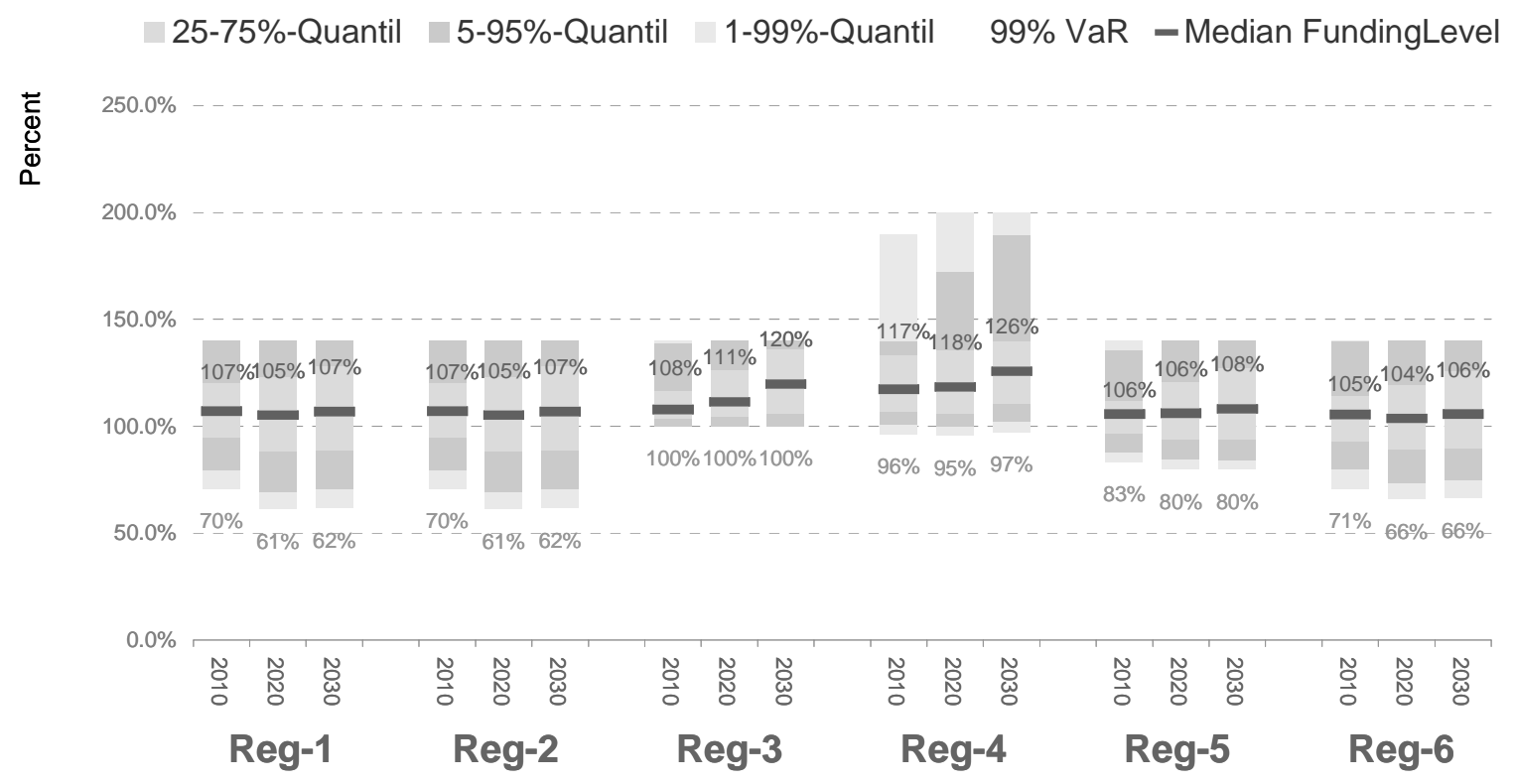




\section{OECD Working Paper on Insurance and Private Pensions}

In Figure 10a and 10b the corresponding regulatory funding levels are shown. As argued earlier, the regulatory funding level under Reg-1 and Reg- 2 is the same as the sponsor's cover ratio, as there are no additional funding regulations. ${ }^{46}$ As expected, the stricter the funding regulations, the lower the range of outcomes in funding levels. In particular, under Reg-3 the funding level never falls below $100 \%$, while under Reg-4, it does not fall below $96 \%$. The funding levels, however, are specific to each regulatory system. For example, a substantial under-funding in 2010 according to Reg-2 of some $30 \%$ would still be an over-funding according to Reg-6.

The example underscores the sometimes very different views between accounting and regulation. Such differences in measuring liabilities cause a dilemma: an ALM optimised investment policy and contribution strategy can only reflect either the characteristics of the DBO used for accounting purposes (here IAS19) or the possibly very different regulatory DBO. This results in a mismatch on either the cover ratio or the funding level. If, for example, the investment policy is tailored to the regulatory funding level, we will see additional volatility of the cover ratio. For Reg-3 we see for example a small surplus risk of the asset portfolio with respect to the DBOReg-3 (6.7\%). However, the volatility of the cover ratio with respect to the DBO-IAS is substantially larger (14.7\%). Regulatory systems that apply a similar methodology to measuring liabilities as that used in the corporate accounting system would reduce cover ratio volatility and allow for a consistent policy framework but may lead to higher net funding costs.

\section{Impact on Net Funding Costs}

In addition to the expected level of net funding costs (median NFC) its risk needs to be considered. The risk is that in adverse economic situations the resulting funding cost could be substantially higher than expected. The "worst case" situation is here described by the $99 \%$ Value at Risk (VaR). ${ }^{47}$ 5a summarizes the resulting median net funding costs (NFC) as well as the 99-percent $\mathrm{VaR}$ for the three sponsors in a final pay plan with indexation, while Table $5 \mathrm{~b}$ shows the same variables for the career average plan with indexation. 
OECD Working Paper on Insurance and Private Pensions

Table 5a. Median and 99 percent Value at Risk of the NFC of a final pay plan with indexation (FP_incr) for the three different sponsors

\begin{tabular}{|c|c|c|c|c|c|c|}
\hline & \multicolumn{2}{|c|}{ HRT } & \multicolumn{2}{|c|}{ MRT } & \multicolumn{2}{|c|}{ LRT } \\
\hline & $\begin{array}{l}\text { Median } \\
\text { NFC }\end{array}$ & $\begin{array}{l}\text { VAR (99\%) } \\
\text { NFC }\end{array}$ & $\begin{array}{l}\text { Median } \\
\text { NFC }\end{array}$ & $\begin{array}{c}\text { VAR (99\%) } \\
\text { NFC }\end{array}$ & $\begin{array}{l}\text { Median } \\
\text { NFC }\end{array}$ & $\begin{array}{c}\text { VAR (99\%) } \\
\text { NFC }\end{array}$ \\
\hline Reg-1 & 375 & 2,416 & 427 & 2,348 & 1,076 & 1,948 \\
\hline Reg-2 & 387 & 2,442 & 446 & 2,430 & 1,089 & 1,989 \\
\hline Reg-3 & 530 & 2,218 & 668 & 2,100 & 1,342 & 2,358 \\
\hline $\operatorname{Reg} 4$ & 577 & 2,301 & 643 & 2,164 & 1,194 & 2,362 \\
\hline $\operatorname{Reg} 5$ & 657 & 2,175 & 720 & 2,099 & 1,310 & 2,257 \\
\hline $\operatorname{Reg} 6$ & 514 & 2,330 & 554 & 2,275 & 1,239 & 2,074 \\
\hline
\end{tabular}

Note: HRT is the high risk taker, MRT is the medium risk taker and LRT is the low risk taker.

Table 5b. Median and 99 percent Value at Risk of the NFC of a career average plan with indexation (CA_incr) for the three different sponsors

\begin{tabular}{|c|c|c|c|c|c|c|}
\hline Figure & \multicolumn{2}{|c|}{ HRT } & \multicolumn{2}{|c|}{ MRT } & \multicolumn{2}{|c|}{ LRT } \\
\hline Regulatic & $\begin{array}{l}\text { Median } \\
\text { NFC }\end{array}$ & $\begin{array}{c}\text { VAR (99\%) } \\
\text { NFC }\end{array}$ & $\begin{array}{l}\text { Median } \\
\text { NFC }\end{array}$ & $\begin{array}{c}\text { VAR (99\%) } \\
\text { NFC }\end{array}$ & $\begin{array}{l}\text { Median } \\
\text { NFC }\end{array}$ & $\begin{array}{c}\text { VAR }(99 \%) \\
\text { NFC }\end{array}$ \\
\hline Reg-1 & 166 & 1,350 & 189 & 1,312 & 623 & 1,052 \\
\hline Reg-2 & 173 & 1,368 & 201 & 1,361 & 631 & 1,065 \\
\hline Reg-3 & 232 & 1,334 & 294 & 1,267 & 829 & 1,326 \\
\hline $\operatorname{Reg} 4$ & 205 & 1,440 & 230 & 1,355 & 710 & 1,120 \\
\hline $\operatorname{Reg} 5$ & 279 & 1,285 & 304 & 1,239 & 779 & 1,248 \\
\hline $\operatorname{Reg} 6$ & 231 & 1,330 & 249 & 1,299 & 726 & 1,144 \\
\hline
\end{tabular}

Note: HRT is the high risk taker, MRT is the medium risk taker and LRT is the low risk taker.

5a and 5b clearly show the impact of strategic asset allocations on the NFCs. The "High Risk Tolerance" NFC is two to three times smaller than that of the "Low Risk Tolerance". The absolute amount of NFC underscore the different effectiveness of the regulation systems given the projection model applied here. It does however not necessarily mean that one system is always more expensive compared to the others. Assumptions about opportunity costs of capital are crucial in the comparison of systems with different absolute initial funding levels. We assume the risk free market interest rate as the relevant opportunity costs. As consequence, regulations with higher contributions towards the end of the period (as under Reg-5 and Reg-6) tend to be more expensive since the pension plan does not earn the risk premium on the plan assets before. The analysis also indicates that regulatory systems with stricter solvency rules and shorter recovery periods 
OECD Working Paper on Insurance and Private Pensions

(such as we find in Reg-3 or Reg-4) reduce the spectrum of possible outcomes and increase the average net funding cost for the "Low Risk Tolerance". The Reg-3 NFC is in fact the highest of all regulatory regimes. This result is determined by the greater exposure to low yielding assets (short term bonds and deposits) that is needed to maintain regularly a high level of funding, as liabilities are calculated using a fixed discount rate of $3.5 \%$. But this higher cost also goes along with higher average funding levels. Interestingly, the highest NFC is that under Reg-5 for the "High Risk Tolerance" and the "Medium Risk Tolerance" sponsor.

\section{Conclusions}

This paper provides a stylised assessment of the impact of investmentrelevant regulations on the investment and contribution policy of DB pension funds. The main findings of the ALM analysis underscore the substantial impact of regulations which, in a simplified way, resemble the basic aspects of the funding regulations in place in Germany, Japan, the Netherlands, United Kingdom and the United States.

The analysis starts with a description of the liabilities of a final pay DB plan with indexation and contrasts them with those of plans without indexation and career average plans. Using demographic and economic data from OECD countries, the liabilities of a final salary plan with indexation are shown to be as much as double those of a career average plan without indexation, given a common accrual rate for both plans. Such cost savings can explain the reforms in plan design observed in occupational pension systems in recent years. In particular, the introduction of conditional indexation by Dutch pension funds in recent years has reduced the average cost of pension provision and introduced a key element of flexibility that will allow the system to better weather storms in the future. The coetaneous move to career-average benefit formulas also has clear advantages from a risk management perspective, but it has not reduced average costs as accrual rates were raised. The flexibility introduced into the Dutch system also contrast with the situation in the United Kingdom, where statutory revaluation and indexation requirements have raised the cost of benefit provision substantially.

The regulatory impact assessment starts by prescribing the valuation methodology for pension liabilities. We find substantial differences among these systems and also compared to the results of the projected unit credit method used in the IFRS accounting framework. Different concepts of recognising accrued benefits (with or without projecting salaries at retirement) and different approaches to discounting future benefit payments 
OECD Working Paper on Insurance and Private Pensions

lead to substantially different measures of liabilities. In particular, under the new international accounting standards (IFRS), pension liabilities increase considerably and become more volatile than under the methodologies prescribed by pension regulators. Additionally, we see different sensitivities regarding changes in interest rates and inflation. Under the regulatory system based on fixed discount rates (which resembles the German case), the liabilities have the lowest volatility and zero sensitivity to interest rate movements (duration). This contrasts with a duration of 22 years for the liabilities measured under IFRS.

The impact of regulations was assessed from the perspective of the sponsor of final salary and career average DB pension plans with guaranteed indexation by measuring their impact on the sponsor's funding costs, its liquidity demands for cash contributions, and the impact of the pension fund's funding status on the volatility of the balance sheet. The impact of regulations was then assessed from the regulator's (and beneficiaries') perspective of keeping the funding level to a prescribed minimum.

The funding costs are mainly determined by the investment performance of the asset portfolio. As in a liability driven investment concept the characteristics of the pension liabilities are the basis for the investment and contribution policy, the optimised asset portfolios differ between regulations, as do the surplus performances of the assets portfolios over the liabilities. An important finding is that, under all regulations, a liabilitymatching asset portfolio that fully replicates the (stochastic) liabilities cannot be derived, as common financial instruments are not able to rebuild the particular characteristics of the liabilities.

Regulations affect funding costs primarily through the choice of investment strategy. Asset regulations imposing quantitative limits on different asset classes reduce the set of otherwise admissible investment policies and can thereby affect funding costs. Funding rules can also have a strong influence on the investment and contribution strategies of pension funds, and hence on the net funding cost. Funding regulations that require full funding at all times and rely on fixed discount rates to calculate liabilities generally lead to higher investment in lower yield, lower risk instruments, raising the net funding cost. Market-based solvency rules in combination with short recovery periods can also have an impact on investment strategies (and hence on funding costs). As there is a risk of high liquidity demands (contributions) in scenarios with abruptly decreased funding levels, sponsors may choose a more conservative asset allocation. From the policymakers' perspective, these higher net funding costs must be traded-off against the lower likelihood of a sudden drop in funding levels and hence a higher level of benefit protection in case of plan termination or bankruptcy of the plan sponsor. 


\section{OECD Working Paper on Insurance and Private Pensions}

Finally, the paper shows that fair-value accounting standards (with immediate recognition of actuarial gains and losses) can contribute to a greater accumulation of assets than required by regulators. On the other hand, the mismatch in valuation methodologies under regulatory and accounting rules creates a dilemma, as the optimisation targets become ambiguous. Low volatility in cover ratios that satisfy sponsors may mean high volatility in funding levels that violate regulatory requirements, especially in countries where discount rates are fixed by regulators. Hence, greater coherence in valuation methodologies under accounting and regulatory standards would go a long way towards facilitating the implementation of optimal ALM strategies by pension funds. This is especially the case for some actuarial assumptions, such as mortality rates.

However, some aspects of the valuation methodology of IFRS accounting standards do not appear suitable for regulatory purposes. In particular, the IFRS measure of pension liabilities incorporates salary projections, which are normally excluded from the regulators' funding level calculations. This is because the regulators' focus is with ensuring the protection of benefits that have been accrued, excluding the revaluation of those benefits if the members were to continue working for the sponsoring company until retirement (as is done under IFRS). The regulator's valuation methods provide flexibility to pension funds to optimise the investment and contribution strategies for the additional funding needed to meet the cost of salary growth and benefit indexation.

The results concerning regulatory impact are specific to the plans modelled, final-pay and career average plans with indexation. Replacing the final-pay benefit formula by a career-average one leads to a lower level of uncertainty over the future evolution of liabilities, hence facilitating risk management. Similarly, making indexation conditional on the funding level (as is the case in the Netherlands) would reduce dramatically the value of the liability to be reported under IFRS on the sponsor's balance sheet. This would allow a more aggressive investment strategy for any buffers needed to finance the pension fund's indexation ambitions. Future research could model specifically how these alternative plan designs are affected by the different regulations reviewed in this study. 
OECD Working Paper on Insurance and Private Pensions

\section{Notes}

1. The model was developed by risklab germany, which also prepared the main empirical results presented in this report. The study benefited from financial contributions from Allianz Global Investors.

2. The regulations considered were those in place up until July 2006. A summary of those regulations are contained in the Appendix.

3. For an overview see e.g. Whittington (2006).

4. See, for example, Klumpes et al. (2003).

5. In the United Kingdom by April 2005, almost half of all UK DB plans active members were in a plan closed to new entrants. This statistic does not include "frozen" or "winding-up" DB plans, that is, plans where there are no longer any active participants (Government Actuary's Department (2006).

6. See Yermo (2007) for a review of the different perspectives taken by accountants and regulators when measuring pension liabilities.

7. There are also operational and governance risks, which are not the focus of this report.

8. See Stewart (2005).

9. For a detailed overview see e.g. Ziemba and Mulvey (1998).

10. Boender et al. (1998) .

11. See Kortleve and Ponds (2006)

12. The UK Myner's Review of the investment industry in 2001 (review available at http://www.hm-treasury.gov.uk/media//843F0/31.pdf) claimed that "asset-liability modelling is a complex number-driven process, in which it is difficult to incorporate asset classes without reasonably long historic time series data. The outcome of such a process is unlikely to be investment in new or poorly researched asset classes, such as private equity. Yet according to investment theory, it is precisely among poorly researched asset classes that greater opportunities for enhanced return are likely to exist. More importantly, the outcome of the asset-liability modelling process depends crucially on a number of prior 
OECD Working Paper on Insurance and Private Pensions

decisions and qualitative judgments, such as assumptions about rates of return, and other economic indicators, and the division of assets into classes (an imprecise art, with elements of arbitrariness)."

13. See Exley et al. (2000).

14. This body of the financial economics literature originated in the United States in the 1970s. One of the first papers was Sharpe (1976). For an overview, see Orszag (2006).

15. See van Rooij et al. (2004) and Vlaar (2005).

16. In some of the countries studied, such as Germany and the United States, this assumption reflects very closely the reality, as the pension fund's governing board is often dominated by the sponsoring company (multi-employer plans in the United States are an important exception). In Japan and the Netherlands, the governing board is supposed to take into account the interest of all stakeholders (including sponsors) in its investment decisions, while the funding decision is taken jointly with the plan sponsor. In the United Kingdom, trustees were granted greater powers by the 2004 Pensions Act and, specifically, were assigned clear duties to set the funding and investment policy. The investment policy has to be consulted with the sponsoring employer, while the funding policy has to be agreed with the company.

17. A good example of a flexible system with risk sharing features can be found in the Dutch system, specifically with respect to the indexation of benefits.

18. See e.g. Vlaar, P. (2005), Boulier et al. (1996) and Van Binsbergen and Brandt (2007).

19. Current discussions among practitioners and academics point out that option valuation methods should be applied for a market consistent and fair valuation of pension liabilities seen as contingent claims. See, for example, Kortleve and Ponds (2006), and Kocken (2006).

20. For the same level of expected benefits, DB plans that pay benefits in the form of lump-sums are cheaper to run and less risky for plan sponsors as longevity risk is fully transferred to plan members.

21. A disability pension is paid in case of disablement before age 65 . Members are entitled to a minimum disability pension: The total rate is at least as high as it would be if he/she reached age 55 as an active member.

22. Widows/widowers receive $60 \%$ of their spouse's current annuity or the disability pension he/she is entitled to respectively. 
OECD Working Paper on Insurance and Private Pensions

23. Note that inflation process is exactly the same as used in the capital market model. This holds also for the bond processes that are relevant for the discount rates.

24. Heubeck Richttafeln 2005 G; for more details, see Heubeck et al. (2006).

25. The German standard table within occupational pensions (Heubeck Richttafeln 2005 G) was used.

26. The simulations using the amortisation and corridor option are available from the authors.

27. See the Appendix for a more detailed description of these regulations in the five countries considered.

28. If revaluation and indexation are not guaranteed (or are conditional on the funding level), the regulatory measure of liabilities does not take them into account.

29. Pension funds are required to reduce surpluses calculated on the basis of the projected unit credit method to max. $5 \%$ within 5 years.

30. The Pension Protection Act of 2006 increased the tax-relevant deductibility limit on contributions to $150 \%$ of the current liability.

31. Of the current liability, measured using the regulator's methodology.

32. See the Appendix.

33. As result Reg-3, Reg-5 and Reg-6 funds have a smaller amount of assets at the beginning compared to Reg-1, while Reg-4 has slightly more.

34. The stochastic scenarios to simulate the financial market environment used for the analysis are produced with the economic scenario generator (ESG) of risklab germany. This structural cascade model provides a consistent set of all underlying driving risk factors.

35. DSP stands for „Dynamic Strategy Portfolio“. In practice such dynamic risk controlling strategies prove to be a very effective instrument for an ongoing control of pension investment risk. The calibration of the risk profile of such a strategy requires some more information on the investor's preferences and circumstances. To avoid extra complexity within the case study the dynamic component is not incorporated into the LDI solutions.

36. For simplicity, we do not consider other risk management instruments such as derivatives and hedge funds.

37. In Reg-3 system, for example, a constant discount rate of $3.5 \%$ is always used, independently of movements of the term structure of interest rates. The underlying liabilities show no sensitivity to interest rate movements. The LDI portfolios for Reg-3 will therefore have practically no duration. 
OECD Working Paper on Insurance and Private Pensions

This is in contrast to the portfolios of the curve for Reg-1 or Reg-2. Here we have a high interest rate sensitivity.

38. See e.g. Dert (1998).

39. See e.g. Vlaar (2005) or Van Binsbergen and Brandt (2007).

40. For technical reasons in order to compare different approaches there will also be further contribution components such as target funding level contributions and comparison contributions. Since (especially in an open ongoing system) there is no final time point where one could compare the systems, we need to make sure that all systems start at the same level and end at the same level.

41. Additional contributions are valued at a lower discount rate. We use the five year corporate yield in order to account for the increased liquidity requirements. Restitutions are discounted with the particular portfolio return. Thus, a risky investment strategy will be valued less positively.

42. To ensure a realistic and tractable picture in such a multi-period and accounting based framework, this approach does not make use of generic utility functions but chooses key business figures that will be considered by the corporate sponsor when judging its financial situation.

43. For the application of state prices in a fair-value approach see Kortleve et al (2006) or Scherer (2006).

44. All simulations used here are performed on risklab germany's proprietary simulation platform. To obtain a detailed picture of the consequences resulting from different investment strategies under different regulations in the simulation analysis some 245 evaluation figures are projected over 30 years into the future.

45. Additional contributions describe the amount of cash contributions, which exceed service costs for a given period.

46. Reg-1 and Reg-2 differ only with respect to payments to the protection fund, which are small relative to the size of the fund. Moreover, these payments do not affect the asset allocation of the fund or its contribution policy, only the net funding cost.

47. Value-at-Risk (VaR) measures the worst expected loss under normal market conditions over a specific time interval at a given confidence level (99\% in this case). VaR answers the question: what's the most I can lose in $\mathrm{x} \%$ of cases over a pre-set horizon. 
OECD Working Paper on Insurance and Private Pensions

\section{Appendix}

\section{Pension fund design and regulations in five OECD countries}

DB pension funds have been traditionally the main form of private pension provision in many OECD countries, but in some there is a growing trend towards plan closures and replacement by defined contribution (DC) ones, especially in Anglo-Saxon countries. ${ }^{1}$ On the other hand, in some continental European countries, such as the Netherlands and Germany, as well as in Japan, DB plans have retained their importance and DC plans have only grown at the margins. These plans, however, have experienced major reforms, as epitomised by the Dutch reengineering of the pension deal (from final salary to career average and from unconditional indexation to conditional indexation).

The following section summarises the salient features of plan design and regulatory approaches. It will focus strongly on investment-relevant regulation, namely the regulation of plan assets, if existent, and funding rules.

\section{Germany: 'Pensionskassen'²}

'Pensionskassen' are special life insurance companies that serve one or several employers. Multi-employer 'Pensionskassen' (when not restricted to a group of companies under common control) are mostly operated by financial service providers or by the social partners. As the latter ones have been founded in the wake of the 2001 pension reform, their market share is still small. In terms of assets under management, company 'Pensionskassen' dominate the market. The German pension fund market is growing strongly, mainly driven by employee-financed pension plans, to which all employees are legally entitled since the 2001 pension reform. Due to the hybrid nature of German pension plans, one might argue that this is more in line with the shift from DB to DC, than the exceptional phenomenon of a growing DB pension market. 
OECD Working Paper on Insurance and Private Pensions

German pension plans are overwhelmingly hybrid. Pure DC plans are legally not permitted; pure DB plans in the form of final salary plans are becoming increasingly rare. The dominating plan type is a 'contribution oriented' DB plan ('Beitragsorientierte Leistungszusage'), which is similar to the cash balance plans in the US. It is basically an average salary plan, where the employer guarantees a pension benefit based on pre-defined contributions. The pension benefit is calculated according to actuarial rules. As the calculation of this pension benefit is based on very conservative estimates, the promised pension benefit is actually a minimum benefit, which usually gets topped up by surplus benefits from investment returns. The 'Pensionskasse' determines the level of the guaranteed interest rate up to a maximum level, which is, in most cases, fixed by the Ministry of Finance (2.25\% since December 2006). The guaranteed interest rate applies for the entire life of a contract. Retirement benefits are most often paid as lifelong pensions. By law, benefits must be indexed. There are different options available, but market practice today is the automatic $1 \%$ indexing of pension benefits for benefits from 1999 onwards. 'Pensionskassen' are mostly exempted from the indexation rule by using all pro rata surpluses to increase the benefits of the pensioners ${ }^{3}$. Today, many 'Pensionskassen' offer a variety of pension plans with different benefit structures employers and employees can choose from.

Germany is the only country of the analysed ones that still applies quantitative investment regulations for plan assets, although the rules have been considerably liberalised over the last years. The regulator defines the investment universe and imposes limits for the maximum investment per asset class or group of classes, which are basically diversification rules. The most important rule is the maximum of $35 \%$ for 'risk-taking assets', mainly equity, but also hedge funds and high-yield assets. German funding rules are strict. 'Pensionskassen' are required to be fully funded at all times with an additional solvency buffer of about $4.5 \%$, which adds up to a required funding level of $104.5 \%$. The 'Pensionskasse' is declared insolvent the moment the funding level falls below $100 \%$. There is no upper funding limit. Germany is the only country covered in this report that does not apply fair value accounting for regulatory purposes. Assets are calculated in nominal terms on the basis of book values, which implies, that capital market volatility translates into hidden reserves (or losses). Liabilities are calculated on the basis of accrued benefits, discounted with the guaranteed interest rate per contract. The discount rate is therefore fixed per contract but does not necessarily apply to the whole balance sheet, which also reflects past discount rates.

EU-wide, the accounting world for the plan sponsor is today mostly governed by IFRS ${ }^{4}$. IFRS applies fair value accounting and calculates 
OECD Working Paper on Insurance and Private Pensions

pension liabilities on the basis of projected benefits, discounted with a rate based on 'high quality' corporate bonds. Actuarial gains and losses have to be included in the disclosure of the balance sheet; the amount exceeding $10 \%$ of the pension obligation has to be amortised and included in the income statement ('corridor approach') ${ }^{5}$. IFRS accounting implies for the plan sponsor, that the pension liability changes significantly compared to the accounting world of the 'Pensionskasse', the liability increases and becomes much more volatile. Therefore, a sponsor might opt for an accounting according to DC rules. As the contributions are in most plans 'pre-defined' and most employers do not guarantee for shortfalls of the 'Pensionskasse' (beyond a general subsidiary liability), the plans are actually very close to a DC plan for the employer. It is further required that the sponsor does not profit from the surpluses of the 'Pensionskasse' in the future.

Due to the strict regulation, German 'Pensionskassen' are conservative and risk-averse investors. Pension fund managers are heavily disincentivised from risk taking because of the lay-offs consequent to insolvency. The maximum investment limit of 35\% for 'risk-taking' assets was tapped with just $18 \%$ at the end of $2005^{6}$. The bulk of the assets are invested in bonds. Since September 2005, ALM is implicitly legally required.

\section{Japan}

Historically, there were two major types of pension plans in Japan, the Employer Pension Funds (EPFs) and the Tax-Qualified Pension Plan (TQPPs). A new type of DB pension plan, the Defined Benefit Corporate Pension Plan (DBCP) has proved popular since its introduction in 2001. This allowed the portion of the EPFs contracted out from the public pension system to be paid back to the government, whilst the remainder of these funds are to be transferred into DBCP schemes (either contract or fund type). This section focuses on the EPFs and the DBCP (which are subject to the same regulation) as the government has required that all TQPPs are wound-up by 2012 .

EPFs are mostly single employer or multi-employer pension funds and provide private pension benefits as well as part of the public pension (substitutional benefits). The stock-market weakness and low interest rate environment experienced by Japan since the early 1990s forced sponsoring employers to make additional contributions in order to meet investment returns related to the substitutional part of the benefits provided by EPFs. The ensuing financial difficulties led to EPFs switching to other types of plans without the substitutional component or to dissolution. The decline in the number of EPFs in recent years is striking. In 1996 there were 1,883 
OECD Working Paper on Insurance and Private Pensions

EPFs $(12,096,000$ participants) while in 2005 only 687 existed $(5,250,000$ participants).

DBCPs have been in existence since 2001 and attempt to offer increased protection to beneficiaries through strict funding requirements and fiduciary duties for the plan management. They have grown at a high pace since their introduction: the 1,432 plans cover 3,840,000 participants (2005).

Most EPFs and DBCPs are career-average salary plans (EPFs substitutional benefits had to mimic those of the public pension system), but recent years have also seen the introduction of hybrid plans such as cash balance plans, where members accumulate monthly pay credits at a specific interest rate per year (for example, $3 \%$ ). Regarding EPFs, the indexation of substitutional benefits (see section on benefit adjustment) is financed by the government. Indexation for EPF's additional benefits and for DBCPs depend on plan rules and are not common. Cash balance plans do not normally provide indexation.

In 1997, a solvency test was introduced for EPFs, which was extended to the new DBCPs in April 2002. If the value of accumulated assets is less than $105 \%$ of the termination liabilities of the contracted-out portion or $90 \%$ of the termination liabilities of total plan benefits (no allowance for salary growth or early leavers, same discount rate for all funds based on risk-free rate, set by Pension Fund Association - 2.2\% in 2005), the shortfall must be eliminated within a maximum period of 7 years. However, if the plan is severely underfunded and the employer is in financial distress, it is possible to reduce benefits. Conditions for reducing accrued benefits include approval by two-thirds of the plan participants and agreement of the labour union. Following further downturns in the stock market, the government introduced temporary relaxations of the minimum funding requirements, including a possible two-year suspension of deficit amortizations and an extension of the 7-year maximum amortization period to 10 years.

Since 1989 there is also a Pension Guarantee Programme, managed by the Pension Fund Association (PFA) to provide termination insurance for EPF plans. The basic principle of invoking the guarantee is that the fund dissolution was caused by bankruptcy or similar financial difficulties of sponsoring companies. Premiums are determined by three components: per capita premiums according to the number of participants; premiums in proportion to the total benefit amount guaranteed; and premiums in proportion to the amount of unfunded liabilities. The maximum of the sum of first two components is set at $Y 8.82 \mathrm{~m}$. The maximum of the third component is set at $Y 0.861 \mathrm{~m}$. The ceiling placed on premiums means that larger companies pay lower guarantee premiums. Currently, premiums are further reduced by $35 \%$ from the sum of these components, as the 
OECD Working Paper on Insurance and Private Pensions

Programme currently holds funds in excess of its targeted contingency reserve.

The Japanese accounting standard is called ASRB and was introduced in 1998 (operative for financial years starting April 1, 2000) among others in order to bring Japanese accounting standards in line with IAS 19. As in the case of IFRS, Japanese employers must recognise their pension liabilities on the balance sheet. The main difference with IAS 19 is that the Japanese standard does not use the corridor method for actuarial gains and losses. Also, the discount rate used to calculate the pension liabilities can be based on yield fluctuations during the previous five years of long-term government or high quality corporate bonds.

Investment regulations were relaxed in 1995, when a series of quantitative ceilings on broad asset classes were eliminated. Since then, pension funds can invest freely under the prudent person standard. In addition, the pension legislation stipulates that each pension fund should endeavour to avoid concentration of investment on a specific asset category and prohibits investment in securities with the purpose of pursuing interests of someone other than the pension fund.

ALM models remain relatively unsophisticated in Japan. Simple models are used, but given funds have been operating in a deflationary environment, these were not taken particularly seriously. Leading international companies such as Hitachi/ Toyota etc. do have regular, professional assessments of their liabilities, but they remain ahead of the curve and in the minority. The responsibility for pension plans has generally shifted from its traditional location within HR departments to finance departments, but the level of sophistication has not increased significantly. Some shift to equities has taken place since the deregulation of asset allocation structures, but bond weightings remain higher than in other countries, partly due to the existence of a liquid government (JGB) market. An important development since the mid-1990s has been the increasing use of hedge funds.

\section{Netherlands}

The Netherlands is still overwhelmingly a 'DB country', but most plans have been transformed from final salary to average salary ones. The Dutch pension funds worked successfully on restoring their financial position via a highly flexible system of burden sharing between the stakeholders.

Retirement benefits are paid as lifelong pensions. Indexation of pension benefits is an explicit goal of the pension policy of the Dutch pension funds, but indexing is neither stipulated by law nor an unconditional commitment of the funds. According to the new pension law, pension funds must 
OECD Working Paper on Insurance and Private Pensions

explicitly declare their indexation policy and the conditions for indexing. With the shift from final salary plans to average salary plans, conditional indexing has become an especially powerful financial steering instrument for pension funds in the context of the pension deal. As only the nominal benefit is guaranteed, the indexation cutting instrument can be applied also to the benefit accruals of the active workers. The change to a conditional index-linked average-salary scheme during the last three years greatly enhanced the pension funds' control over their pension benefit levels.

Regulation is changing in the Netherlands. The new pension law was implemented in 2007. As the new law has been under discussion for quite some time, the effects in the market will probably be small. At the heart of the Dutch regulation lies a risk-based approach. Pension funds have to fully fund their nominal liabilities with a solvency buffer of 5\%. The probability of undershooting $100 \%$ may not be larger than $2.5 \%$, which has to be proven in a solvency test. According to model calculations by the regulator ${ }^{7}$, this will require the average pension fund to be funded at approximately $130 \%$. If the pension fund falls below $105 \%$, they have a recovery period of 3 years. If a pension fund has a funding level between the targeted solvency balance (130\% for the average fund) and the minimum funding level $(105 \%)$, it is requested to prepare a recovery plan with a planned recovery period of up to 15 years, which must get approved by the regulator. Pension funds also have to pass a continuity test every three years, where they have to prove their long-term financial stability, including their indexation objectives, on the basis of an ALM study. The solvency test can be performed in three ways, which differ with regard to their complexity and sophistication. The most sophisticated way in terms of risk management to perform the solvency test is the application of internal models, which were introduced to the banking industry with Basle II. Unfortunately, the parameters were chosen in a way that internal models will not be rewarded and therefore are unlikely to get implemented. In this respect, the Dutch regulation falls one step short of implementing a really sophisticated, riskbased regulation.

Investment regulations will not be affected by the new pension legislation. Current regulations are based on the prudent person standard. There are no investment ceilings other than a 5\% ceiling on investment in the sponsoring employer (10\% in the case of employer groups).

Under new legislation, Dutch regulation will be based on the fair value principle. Pension liabilities are calculated on basis of the accrued, nominal benefits, discounted with the term structure of Zero-Coupon interest rates. Indexation of benefits can be paid either by contributions or by investment returns or a combination. Conditionally indexed benefits are not included in the funding rule. The funding position of the Dutch pension funds was $125 \%$ 
OECD Working Paper on Insurance and Private Pensions

at the end of 2005. A funding level of $150 \%$ is needed in order to achieve $100 \%$ funding in real terms (i.e. including revaluation and indexation objective).

The large industry-wide pension funds, which prevail in the Netherlands, have usually been classified as DC plans according to the Dutch standard RJ271, although the plans offer DB like features to the employees. The rationale is the low risk of additional contribution to the sponsor, due to e.g. the conditionality of indexation, the cost of which are also shared between employers and employees and pensioners. For all companies, which have to apply the IFRS accounting rules, this accounting practise would have become unsustainable, even if their pension fund is part of an industry-wide fund. This provision is still under debate in the Netherlands. Meanwhile, the IFRS regulations have triggered a move to Collective Defined Contribution (CDC) plans $^{8}$, in order to get the plan classified as DC. Pension funds fix the contributions for 5 to 10 years, withdraw the shortfall-guarantee but also give up the right to recover surpluses.

The Dutch pension funds are highly sophisticated investors. They are very liability orientated and deliberate risk-takers. ALM on a yearly basis is already market practice and has become mandatory with the new pension law. The SAA stayed virtually unchanged over the last years, with about $40 \%$ in bond and equity each ${ }^{9}$, but - according to market experts - about $1 / 3$ of Dutch pension funds has implemented an overlay strategy based on derivatives to hedge out the downward risk. Trustees are rewarded for risktaking as they can use the superior return for indexing. Therefore, liabilitymatching investment strategies are not popular in the Netherlands.

\section{United Kingdom}

The most significant current trend in UK private sector pension provision is the retreat by employers from providing defined benefit schemes. Some of these schemes are amended to be career average schemes, but often they are not amended but closed to new members. When this occurs existing members can usually stay in the schemes and continue accruing benefits. New members are frequently offered a DC plan instead often with significantly lower employer contributions ${ }^{10}$.

Retirement benefits are usually provided as lifelong pensions, often with an option to exchange up to $25 \%$ of the pension for a cash sum, paid free of tax. For pensions in payment, Limited Price Indexation must be applied to certain elements of the pension. Pensions in payment, which accrued after April 1997, must be indexed as a minimum in line with the lower of the 
OECD Working Paper on Insurance and Private Pensions

retail price index (RPI) and a fixed rate of 5\% p.a. From 2005 onwards this fixed rate was reduced to $2.5 \%$ p.a. Many funds also index pensions which accrued before 1997 at the same or similar rates. The indexation of deferred benefits is also a legal requirement in line with the indexation of pensions in payment.

UK pension regulation is changing significantly but incrementally. In general, regulation has become more risk-focused, looking closer at the funding level of pension funds and the covenant of the plan sponsor. Companies are encouraged to accelerate the funding of their pension funds' deficits. The Pensions Act 2004 established the 'Pension Protection Fund' (PPF), a protection scheme for pension benefits, as well as a new regulator: 'The Pensions Regulator'. The new regulation aims to protect the benefits of scheme members while avoiding the threat of 'moral hazard' inherent in the US system. Therefore, the PPF levy is partly risk-based, taking into account the covenant of the plan sponsor and the funding situation of the pension scheme. Also, a new funding regulation was introduced, but - unlike in other countries - not clearly specified, as the UK regulation is scheme-specific and principle-based. Pension funds are required to adopt a 'Statutory Funding Objective', set out in a statement of funding principles. In general, funds should have 'sufficient and appropriate assets to cover their technical provisions (essentially their accrued liabilities) ${ }^{11}$. In case of a shortfall, the trustees have to prepare a recovery plan. As the new regulations are being phased in over 3 years with the forthcoming actuarial valuations, a new market practice has not yet evolved. To give the market some orientation, the Pension Regulator released its 'trigger points' for intervention, while stressing that these are not funding targets. In general, a funding target of either less than $100 \%$ in a PPF or IFRS valuation and/or a recovery period of more than 10 years may trigger some further investigation by the regulator.

Since pension schemes all use their own actuarial assumptions and valuation methods, for reasons of comparison, the valuation rules of the accounting standard FRS 17 are usually applied, although they apply for disclosure in the plan sponsor's accounts only and not for the funding of the pension scheme itself,. On a FRS 17 basis, UK pension funds are about $85 \%$ funded with a combined deficit of around GBP $40 \mathrm{bn}^{12}$. For accounting periods from 2005 onwards, UK listed companies are under EU law required to adopt IAS19. The two accounting standards are being harmonised, and both will require the recognition of the pension scheme asset or liability on the balance sheet, with pension fund deficits directly reducing shareholders' equity.

When a plan sponsor seeks to terminate the pension plan, he is liable to the buy-out liability with an insurance company. The buy-out liability will most often significantly exceed the pension liability in a regulatory or even 
OECD Working Paper on Insurance and Private Pensions

accounting valuation ${ }^{13}$. Nevertheless, the interest of plan sponsors in disposing of their 'legacy cost' seems to be high, as is indicated by a number of new entrants into this potentially lucrative market.

As in the Netherlands, investment regulations are based on the prudent person standard. There are no investment ceilings other than a 5\% ceiling on investment in the sponsoring employer.

In general, the discussion on the proper risk, a pension fund should take in its investment policy has become quite polarised in the UK. While most pension funds still adhere to the high risk-profile of the 'old 70:30 balanced mandate', where $70 \%$ of the assets are invested in equity and $30 \%$ in bonds, many have or are seeking to adopt 'Liability Immunisation Strategies', thereby significantly reducing investment risk, but also potentially decreasing investment returns and thus increasing the long-term costs for the sponsor. Although LDI strategies are still a much discussed niche product with $5 \%-10 \%$ of overall pension fund assets estimated to be invested in LDI products, the change in the market SAA is already obvious, the equity exposure has been lowered from around $70 \%$ to around $60 \%$ with the balance being invested in lower-risk assets ${ }^{14}$.

\section{United States}

In spite of the long-term, steady shift from DB to DC, DB pension plans still account for about $50 \%$ of pension assets under management in the US. Of those participants covered by DB plans, about $77 \%$ are covered by a traditional plan, of which over half have a final salary plan. However, despite some legal uncertainties that have slowed their adoption since the late $1990 \mathrm{~s}$, cash balance plans ${ }^{15}$ have slowly gained in importance, and currently cover about $21 \%$ of DB plan participants ${ }^{16}$. Many large companies, particularly those in manufacturing and other older industries offer both DB and DC plans ${ }^{17}$.

Although sponsors of DB plans are legally required to offer retirement benefits in the form of an annuity, about half of all participants have the option of receiving their benefit in the form of a full or partial lump sum. There is a huge variety of plan formulas among DB plans. Indexation is neither legally required nor market practice. Pension plans, especially those that are not collectively bargained, have to pass a series of coverage and eligibility test in order to maintain their tax-exempt status. To ensure compliance with these tests, most private sector employers established noncontributory plans (the contribution is paid by the employer only), where each member of the workforce is automatically enrolled upon meeting certain minimum requirements. 
OECD Working Paper on Insurance and Private Pensions

In August 2006, the Congress enacted comprehensive pension reform legislation. This new law, the Pension Protection Act of 2006, was aimed at improving the financial stability of the DB pension system and reducing the financial pressures on the 'Pension Benefit Guaranty Corporation' (PBGC), the government agency that insures benefits for private pension participants. In recent years, the PBGC has suffered a deterioration of its finances The PBGC's net position fell from a surplus of USD 7.7.bn in 2001 to a deficit of USD 18.4bn in November 2006 for its single-employer insurance program, due to the termination of a number of large underfunded pension funds by bankrupt sponsors, mainly in the steel and airlines industry. Given that at least several of these had been considered as adequately funded under the old regulatory regime, a consensus emerged that the existing plan funding rules were seriously deficient. ${ }^{18}$. For example, under the old funding rules, sponsors were required to fund to between $90 \%$ to $100 \%$ of the plan's current liability ${ }^{19}$, but were given considerable leeway in choosing the actuarial assumptions and methodology to reduce their contributions. At funding levels below 90\%, sponsors were required to increase their contributions although other provisions had the actual effect of few sponsors ever making these additional contributions. In addition, sponsors had to be cognizant of not making too large a contribution in any single year to avoid exceeding the plan's maximum deductible contribution, which could threaten the plan's tax-exempt status. At least for some plans, this strict upper funding level prevented pension plans from accumulating reserves in times of good investment returns.

Under the Pension Protection Act 2006, US pension funds will ultimately be required to fully fund their pension liabilities. At first, the extension of relief measures to 2006 and 2007 - mainly the use of corporate bonds as discount factors for calculating the deficit reduction contribution as compared to the yield on 30-year Treasury Bonds - gives pension funds a 'funding break'. From 2008 onwards, pension funds are required to accelerate their contributions to amortise deficits over seven years. Pension liabilities will be discounted using a simplified yield curve based on a twoyear average of high-grade corporate bonds. Actuarial assumptions and valuations methods will be prescribed by law. Furthermore, the funding level will affect not only employer's contribution, but also employees' benefits: If a pension fund is funded below $80 \%$, the pension fund may not increase benefits, below $60 \%$ funding the accrual of promised benefits is stopped; benefits are actually frozen. Some smoothing mechanisms for assets, liabilities and contributions will be still available, but restricted to 2 year-averages. The tax-relevant deductibility limit on contributions will be increased to $150 \%$ of the current liability already from 2006 onwards. While these measures are expected to increase the funding level of US pension 
OECD Working Paper on Insurance and Private Pensions

funds, they are also likely to increase the volatility of contributions for the employer.

Besides the changes enacted in the Pension Protection Act, plan sponsors will also have to operate under a different set of accounting rules. According to the current rules, plan assets can be measured applying up to 5-year averages of market values. As under IAS 19 and FRS 17, liabilities have to be calculated as the projected benefit obligation. FASB's current rules regarding interest rate assumptions have been comparatively vague, requiring the discount rate to reflect the rate at which the pension benefit can be efficiently settled, but not prescribing a specific interest rate. Consequently, the use of the long-term expected rate of return on the plan's assets was widespread. For actuarial gains and losses the same smoothing mechanism are available as under IFRS rules. As the accounting rules were widely criticised for not reflecting the financial situation of pension funds ${ }^{20}$, FASB set up a review project with two phases. FASB recently issued the results of phase one, which will apply from 2007 onwards. The first major change is that the funded status of the pension fund has to be explicitly recognised on the balance sheet and not simply acknowledged in the notes. In addition, plan assets and liabilities have to be recognised in the year in which they occur and measured as of the date of the financial statement. The second and more important change refers to the discount rate for valuing pensions, which must now be based on the yield of high-quality bonds instead of the expected rate of return on plan assets. Phase two comprises a new assessment of pension accounting and will take some years to complete and implement. Together, all of these changes imply that from 2007 onwards, also US companies will be exposed to considerable volatility due to pension funds in their accounting systems.

Investment regulations are based on the prudent expert principle, following modern portfolio theory. There are no quantitative investment ceilings other than a $10 \%$ ceiling on investment in the sponsoring employer, but extensive qualitative regulations, mainly via litigation.

The governance of US pension funds clearly provides incentives for risk taking by the pension fiduciaries. US pension funds are the only investor group analysed in this project that have actually increased the risk level of their portfolio by moving out of bonds and into alternative assets. Although LDI has not yet reached the US market, this is widely expected to change under the new pension regulations, and the U.S. Labor Department has already accepted LDI strategies as conforming to the fiduciary requirements under ERISA ${ }^{21}$. 
OECD Working Paper on Insurance and Private Pensions

\section{Notes}

1. This trend is most conspicuous in the United Kingdom, where as many as $60 \%$ of all DB plans are now closed to new entrants while over $10 \%$ have also stopped accruals for existing employees (NAPF estimates).

2. For Germany, this report will focus on 'Pensionskassen' only, as this is the most relevant and best documented funded pension vehicle in Germany. But the reader should keep in mind that it is only one in five available financing vehicles and accounts for roughly $20 \%$ of the German market for occupational pension plans.

3. According to the actuarial consultant firm BodeHewitt AG \& Co. KG.

4. Smaller, not capital-market relevant companies can still apply the commercial code HGB, which also covers the 'Pensionskasse'.

5. The second possible approach under IFRS is the 'SoRIE' approach: Gains and losses are recognised on the balance sheet in full immediately; but via a separate 'Statement of Recognised Income and Expense' (SoRIE), not in the profit and loss account.

6. Bundesanstalt fuer Finanzdienstleistungsaufsicht, Jahresbericht 2005.

7. Pensioen en Verzekeringskamer, 2004, Financial Assessment Framework Consultation Document, Apeldoorn.

8. According to market experts, at least 15 pension funds have already changed to $\mathrm{CDC}$, and about $1 / 3$ of the company pension funds say they are considering the change.

9. See Kakes, J. (2006), 'Financial behaviour of Dutch pension funds', DNB Working Paper no. 108.

10. Theoretically, the change from DB to DC should be accompanied by higher contributions as a price for the risk, which is transferred from the employer to the employee.

11

http://www.thepensionsregulator.gov.uk/codesAndGuidance/codes/inForc e/definedBenefit/index.aspx

12. 2005 NAPF Annual Survey, Pension Fund Investment. 
OECD Working Paper on Insurance and Private Pensions

13. Lane, Clark \& Peacock estimates the total buy-out deficit of the FTSE 100 companies at over GDP 176bn in July 2006 compared to an IAS19 deficit of GBP 36bn (see: 'Accounting For Pensions: UK and Europe, Annual Survey 2006').

14. NAPF, Annual Survey 2005, September 2005.

15. Cash balance plans combine features of DB and DC plans. The employer specifies a contribution and guarantees an interest rate on that contribution. However, the accounts for individual participants are notional, and the plan is funded and invested by the plan sponsor. Benefits earned through participation in a cash balance plan are insured by the PBGC up to certain limits. In addition, although cash balance plans must offer participants the option of receiving their benefits in the form of an annuity, at retirement are usually paid as a lump sum.

16. See US Department of Labor (2006) Private Pension Plan Bulletin.

17. See: Mercer (2005). How Does Your Retirement Program Stack Up?

18. See e.g. United States Government Accountability Office: Report to Congressional Committees, May 2005, 'Private Pensions: Recent Experiences of Large Defined Benefit Plans Illustrate Weakness in Funding Rules'.

19. The current liability is the present value of accrued benefits calculated using partly mandated assumptions, e.g. mortality table, and a discount rate based on the yield of 30-year Treasury Bonds. It is calculated on a plan termination basis.

20. See e.g. Ryan, R., and Fabozzi, F. 'Rethinking Pension Liabilities and Asset Allocation', in: The Journal of Portfolio Management, 2002, pp. 715.

21. see: http://www.dol.gov/ebsa/regs/aos/ao2006-08a.html 


\section{References}

van Binsbergen, J. H. and Brandt, M. W. (2007), "Optimal Asset Allocation in Asset Liability Management", NBER Working Paper \#12970, March 2007.

Boender, G. C. E., van Aalst, P. and Heemskerk, F. (1998), "Modelling and management of assets and liabilities of pension plans in the Netherlands." in Worldwide Asset and Liability Modelling, J. M. Mulvey and W. T. Ziemba (eds.). Cambridge, Cambridge University Press: pp. $561-580$.

Boulier, J., Michel, S., and Wisnia, V. (1996) "Optimizing investment and contribution policies for a defined benefit pension fund", AFIR Colloquium.

Dert, C. (1998), 'A Dynamic Model for Asset Liability Managing for Defined Benefit Pension Funds', in Worldwide Asset and Liability Modelling, Mulvey, J. and W. Ziemba (eds.).

Exley, J., Mehta, S. and Smith, A. (2000) 'Asset and Liability Modelling for Pension Funds', paper presented to the Joint Institute and Faculty of Actuaries Investment Conference June 2000.

Government Actuary's Department (2006), "Occupational Pension Schemes 2005: The thirteenth survey by the Government Actuary", London: The Government Actuary's Department, June 2006.

Heubeck, K., Herrmann, R., D'Souza, G. (2006), 'Die Richttafeln 2005 G Modell, Herleitung, Formeln', DGVFM-Blätter, April 2006.

Kochen, T. P. (2006), Curious Contracts: Pension Fund Redesign for the Future, 's-Hertogenbosch: Tutein Nolthenius.

Kortleve, N. and Ponds, E. (2006), "Pension deals and value-based ALM", in Niels Kortleve, Theo Nijman, and Eduard Ponds (eds.) Fair Value and Pension Fund Management, Oxford, Amsterdam, Elsevier: pp. 181-209.

Kortleve, N, Nyman, T. and E. Ponds, edited, (2006), Fair Value and Pension Fund Management, Oxford, Amsterdam, Elsevier. 
Klumpes, P., Li, Y. and Whittington, M. ( 2003), "The Impact of UK Accounting Rule Changes on Pension Terminations," Warwick Business School Working Paper, August 2003.

Orszag, J. M. and Sand, N. (2006), "Corporate Finance and Capital Markets". in the Oxford Handbook of Pensions and Retirement Income. G. L. Clark, Alicia H. Munell and J. Michael Orszag (eds.), Oxford, Oxford University Press: pp. 399-414.

van Rooij, M., Siegmann, A., and Vlaar, P. (2004), "A Pension Asset and Liability Model for the Netherlands", DNB Research Memorandum WO no 760, April 2004.

Scherer, B. (2006) (ed), "Asset and Liability Management Tools: A Handbook for Best Practice", B. Scherer. London, Risk Books.

Sharpe, W. (1976), 'Corporate Pension Funding Policy', in the Journal of Financial Economics 3/2, pp. 183-93.

Stewart, F. (2005), "Developments in Pension Fund Risk Management in Selected OECD and Asian countries", www.oecd.org/dataoecd/38/52/34030924.pdf.

Vlaar, P. (2005) "Defined benefit pension plans and regulation", $D N B$ Working Paper No. 63, De Nederlandsche Bank, December 2005.

Whittington, G. (2006), 'Accounting Standards for Pension Costs', in 'The Oxford Handbook of Pensions and Retirement Income' Gordon L. Clark, Alicia H. Munnell, and J. Michael Orszag (eds.), Oxford University Press, 2006; Oxford.

Yermo, J (2007), "Reforming the Valuation and Funding of Pension Promises: Are Occupational Pensions Safer?", in Protecting Pensions: Policy Analysis and Examples from OECD Countries, Private Pension Series No. 8, OECD: Paris.

Ziemba, W. T., J. M. Mulvey, et al. (1998), Worldwide asset and liability modeling, Cambridge, Cambridge University Press. 